\title{
フィリピンラハール竾害地域
}

\section{Pasig-Potrero・Porac 川流域における地下水流動と地下水涵養}

\author{
平出重 信 ${ }^{1)}$ 渡邊眞 紀子 ${ }^{2)}$ 衣笠 善 博 ${ }^{2)}$ \\ 森島 済 ${ }^{3)}$ RONDAL, J.D. ${ }^{4)}$ COLLADO, M.B. ${ }^{4)}$ \\ 鈴 木 浩 一 $\left.{ }^{5}\right)$
The Groundwater Flow and Recharge in Lahar Disaster Area, Pasig-Potrero and Porac River Basins, Philippines \\ Shigenobu HIRAIDE ${ }^{1)}$, Makiko WATANABE ${ }^{2)}$, Yoshihiro KINUGASA ${ }^{2)}$, \\ Wataru MORISHIMA ${ }^{3)}$, J.D. RONDAL ${ }^{4)}$, M.B. Collado ${ }^{4)}$ \\ and Koichi SUZUKI ${ }^{5}$
}

\begin{abstract}
Pyroclastic deposits of the Mt. Pinatubo eruption in 1991 have been transported as Lahar (Mud flow) by rainfall and inflicted damage to the area surrounding the Mt. Pinatubo. changes in the quality and quantity of groundwater have affected the regional community, which mainly depends on underground water for water resources.

The purpose of this study is to understand groundwater flow and recharge in the Lahar disaster area around Pasig-Potrero and Porac river basins, Pampanga province, Philippines.

Resistivity sounding was applied to measure underground water level, and a water analysis was conducted to understand the regional distribution of ion concentration.

A landform classification was carried out to consider the influence of landforms on underground water flow and regional distribution of water quality. The former landforms (before 1991 eruption) were classified into mountain, alluvial fan at volcanic foot, alluvial fan (Porac, Pasig, Abacan), delta, and flood plain. Underground water flow and regional distribution of water quality were prescribed by these former landforms, except in the area surrounding Sand-Pocket. From the fact that the deposition of lahar in Sand-Pocket has raised the bed of Pasig-Potrero River, it is considered that river water has intended to

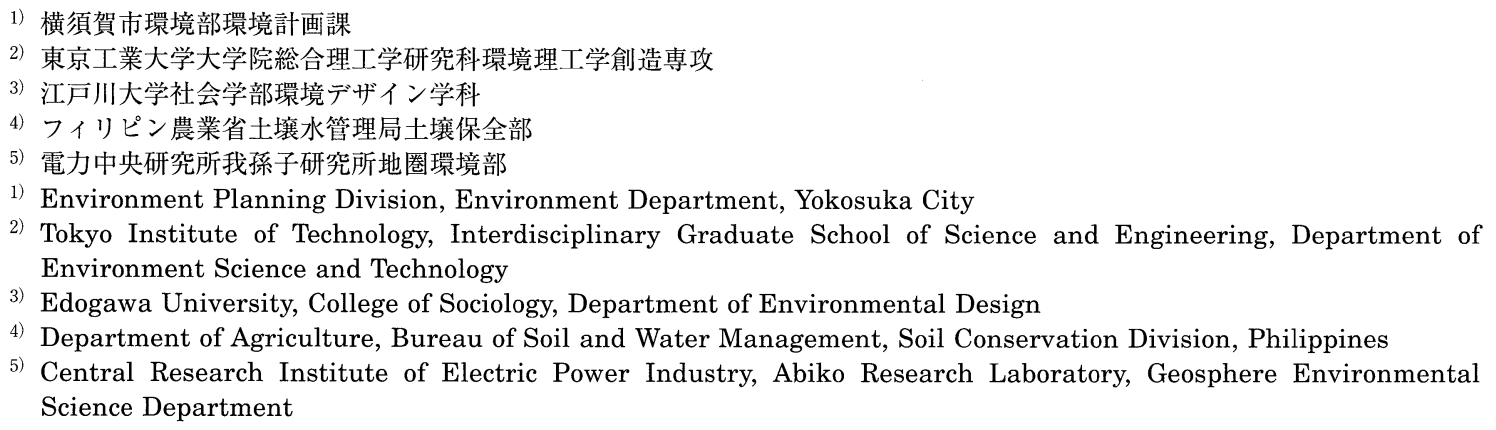


infiltrate into the underground water in the area surrounding Sand-Pocket. The influences of former landform and artificial landform (Mega Dike) were pointed out as factors regulating characteristic underground water flow and distribution of water quality in this area.

Spatial distribution and seasonal changes of underground water flow and water quality were obtained from observed results of resistivity soundings and analytical results of water quality. Underground water flow, which had small seasonal changes, was classified into 3 regional groups $(I \sim \mathbb{I I})$. The existence of a peculiar regulating factor for underground water flow was suggested. In addition, monthly changes of water level indicate a translocation of the recharge area. The propagation speed of recharge area was related to the true speed of the translocation of recharge area, which was estimated from the results of a pumping test and from calculations of the apparent velocity of underground water flow. Furthermore, the distribution of $\mathrm{SO}_{4}{ }^{2-}$ concentration showed a good correspondence with underground water flow. In particular, the high concentration area of $\mathrm{SO}_{4}{ }^{2-}$ was distributed inside the Mega-Dike. From the results obtained, a model was suggested to explain the formation of water quality in this area characterized by the underground water flow from Pasig-Potrero River.

From above results, groundwater flow and recharge in Lahar disaster area around PasigPotrero and Porac river basins were understood.

Key words : Philippines, volcano, lahar, underground water flow, landform キーワード：フィリピン, 火山, ラハール, 地下水流動, 地形

\section{I. はじめに}

1991 年 6 月のフィリピン・ピナツボ山噴火に よって周辺地域に供給された土砂は, 雨季の降雨 によって泥流（ラハール）となり, ルソン島ター ラック，パンパンガ，ザンバレスの 3 州を襲った。 この泥流によって河川の流路が変化するともに, 泥流の堆積・侵食による地形の急激な変化は, 地 下水の流動にも大きな影響を与えている。

また，ピナツボ山の噴火にともなって，火山性 物質がピナツボ山周辺に供給された。特に硫黄は 火山噴出物に多量に含まれ (Imai et al., 1993), 全 火山噴出物中には $9.6 \times 10^{6} \mathrm{~m}^{3}$ もの硫黄が含まれ ると試算されている（吉田・太田，2002）。これら の硫黄分は, 辻 (1986) が浅間山と有珠山の火山 灰を用いて示したように, 降雨によって溶出・洗 脱しやすく, 溶出した硫黄分は河川水や地下水に 流入すると考えられる。実際に, ピナツボ山を源 とする河川の周辺では, 地下水から高濃度の硫酸
イオンが検出されている（図 1)。高濃度の硫酸イ オンは健康被害を生じるものとして, フィリピン や米国の飲料水基準で $250 \mathrm{mg} / \mathrm{l}$ がその上限とさ れている（榆井, 1993; 小椋, 2000）ことに加え， 高濃度の硫酸イオンは, 硫酸還元によって生じた 硫化水素により水稲の根が黒色化し根腐れする 「秋落ち」現象を引き起こす要因ともなり（渡邊， 2002)，地下水利用のうえで問題となっている。

フィリピンでは上水道の整備が遅れており, 上 水道の生活用水に対する普及率は, 農村部で $27.2 \%$, 都市部でも $45.7 \%$ と低い值を示す一方で, 地下水が生活用水に占める割合は農村部で $57.4 \%$, 都市部でも $30.6 \%$ と高い割合を示し(小椋, 1999)， 地下水は市民生活の水資源として重要な地位を占 めている。本地域においても都市部の一部を除い て水道施設の整備が遅れており, 生活・灌溉用と もに，地下水に対する依存度は高い。さらに，ピ ナツボ山の噴火によって河川周辺の灌溉施設が破 壊されるとともに，地形変化にともなう水系の変 


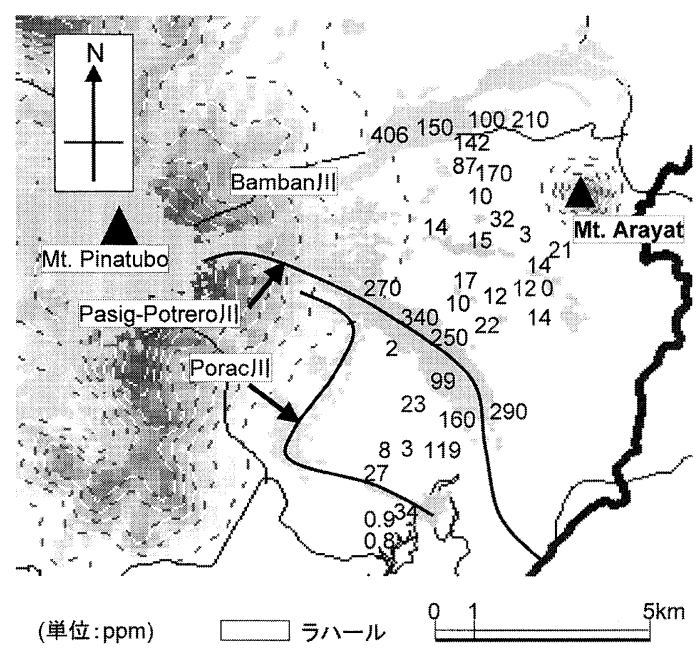

図 1 ラハール災害地域における河川水と井戸水 の $\mathrm{SO}_{4}{ }^{2-}$ イオン分布 (1998 年 5 月).

Fig. 1 Regional distribution of $\mathrm{SO}_{4}{ }^{2-}$ ion of underground water and river water in Lahar disaster area (May 1998).

化によって，一部地域においてはクリークを用い た灌溉などが困難となっており，水資源に占める 地下水の役割は増大していると言える。

このため，ラハール災害地域における地下水の 現状を量・質の両面から総合的に把握することが 急務となっている。そこで本研究では, ラハール 災害地域のうち, メトロマニラの重要な後背地で あるピナツボ山東側パンパンガ州のラハール災害 地域を対象として（図 2), 観測孔の設置と電気探 查法による地下水探査により地下水位を把握し, 観測孔と既存孔から採取した水の分析 $\left(\mathrm{SO}_{4}{ }^{2-}\right.$ 濃 度）結果と合わせて，地下水流動と地下水涵養源 の形態を明らかにすることを目的とする。また， 地形分類からも両者の地下水流形態を明らかにす る。

\section{II. 研 究方法}

\section{1）観測孔の設置と地下水位の観測}

地下水の観測孔（深度約 $20 \mathrm{~m}$ ) を計 16 力所 （図 3）掘削した。図 3 における L1 は標高 $50 \mathrm{~m}$ に沿って設置された観測孔，L2 は標高 $70 \mathrm{~m}$ に

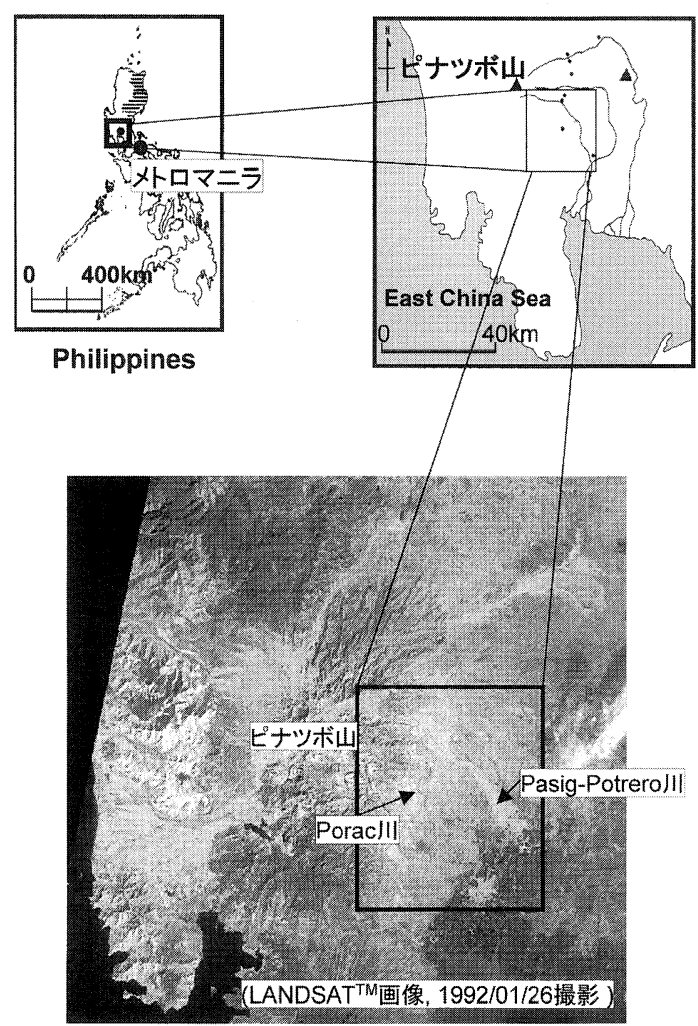

図 2 ピナッボ火山と周辺のラハール分布域（淡色 域).

衛星画像の枠は調査地域を示す.

Fig. 2 Distribution of Lahar at surrounding area of Mt. Pinatubo (Light colored area).

Frame of satellite image shows study area.

沿って設置された観測孔群を示す。これらの観測 孔に拈いて，簡易水位計（ヤマト製，ミリオン水 位計）を用い，地下水位を 2001 年 7 月〜 2002 年 9 月の毎月，および 2002 年 11 月に観測した。掘 削孔には $25 \mathrm{~cm}$ 間隔で直径 $5 \mathrm{~mm}$ の孔をあけた塩 化ビニル製の孔明管を挿入た。また， 2001 年 3 月にボーリング調査を行った Site Q においても, ボーリング孔を利用して，2001 年 7, 11 月，およ び 2002 年 6, 11 月に地下水位の観測を行った。

\section{2) 電気探査}

平出ほか $(2001,2002)$ によって, 調査地域に おける比抵抗法垂直探査の地下水探査手法への適 用性が認められている。そこで本研究では, 比抵 


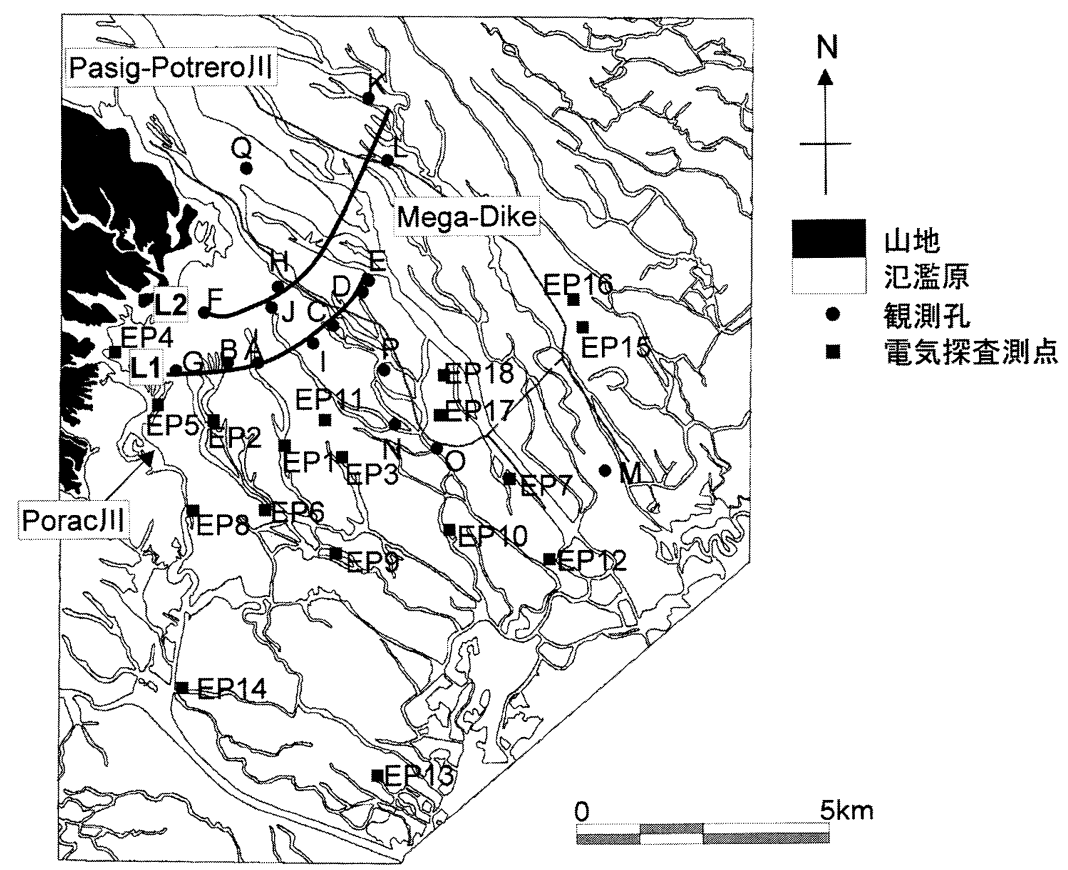

図 3 観測孔と電気探査測点の位置.

Fig. 3 Location of observation well and measurement point of resistivity sounding.

抗法垂直探査（ウエンナ法）を用いて地下水位の 把握を行った $(2001$ 年 7,11 月;各 3 測線, EP1 ～3，2002 年 3 月; 10 測線, EP1 10, 2002 年 6 月, 18 測線, EP1 〜 18)（図 3)。測定には比抵

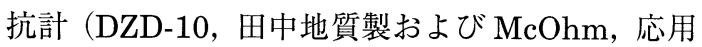
地質製）を用いた。解析には 1 次元インバージョ ン（牛島ほか，1987）を用い, 地層は不飽和層・ 飽和層・不透水層（飽和層）の 3 層からなると仮 定し解析を行った。なお本研究では, 比抵抗法垂 直探査の解析結果から得られる地下水位は, 飽和 層（水で飽和された間隙を持つ飽和帯と毛管水で 飽和された毛管帯の総和）と不飽和層（水が蒸発 や植物の作用で大気中に相当量放出される懸遊带 と土畩水を含むフニクラ带の総和）の境界面と定 義し, 観測孔で実測される地下水位と同義のもの として使用する。

\section{3) 水質分析}

地下水のサンプル採取にあたっては, 既存の生 活用・灌溉用井戸から直接サンプルを採取すると
ともに，観測孔より，2001 年 7 月〜 2002 年 9 月 の毎月サンプルを採取し水質の定期観測を行った。 また, 2001 年 3 月にボーリング調查を行った Site Q（Mancatian）においても，ボーリング孔 を利用して，2001年 7, 11 月，および 2002 年 6 月にサンプル採取を行った。

水質分析項目と方法は以下の通りである。

- $\mathrm{Ca}^{2+}, \mathrm{Mg}^{2+}, \mathrm{N}^{\mathrm{a}+}, \mathrm{K}^{+}$: 原子吸光法（原子吸光光 度計 HITACHI 170-30, HITACHI Z-5700 を使 用)

$\cdot \mathrm{SO}_{4}{ }^{2-}$ : 硫酸バリウムによる白濁を利用する比濁 法（紫外可視分光光度計 HITACHI U-2001を 使用)

$\cdot \mathrm{Cl}^{-}$: 滴定法 (Silver Nitrate Titration Method)

$\cdot \mathrm{HCO}_{3}{ }^{-}$: 滴定法（アルカリ度測定）

· EC (電気伝導度) : ECメーター東西電波 CM14P を使用

\section{4) 地形分類}

地形分類にあたっては，5万分の 1 の地形図 
（1990 年発行）をもとに，1万分の 1 の航空写真 （1991 年撮影）を用いて分類を行った。また調査 地域のうち，航空写真を入手することができな かった地域については 10 万分の 1 の土壌図 (1940 年発行，土性の区分等は Alicante et al. (1940), Teodomero et al.（1956）を参考にした）を用い て情報を補足するとともに, 地形図の等高線の形 態から地形を判別した。なお地形区分は守屋 (1978), 大矢 (1983), 鈴木 (1997) を参考に 行った。

\section{III. フィリピンピナツボ山噴火と調查地域概要}

\section{1）ピナツボ山と噴火の概要}

ピナツボ山はメトロマニラから北西約 $100 \mathrm{~km}$ に位置し（図 2）, マニラ海溝にともなう火山弧の 中で最高峰をなす安山岩質からデイサイト質の火 山である。最も古い值を示す噴出物の年代值は 1.1 $\mathrm{Ma}$ で, 約 600 年前に $2 \mathrm{~km}^{3}$ に及ぶ火砕流堆積物 を形成した噴火があったことが知られている (Wolfe and Self, 1993)。Newhall et al. (1995) は, 1991 年の噴火以前にも, 後期更新世から歴史 時代で少なくとも 6 回噴火しているとし，その噴 火年代を ${ }^{14} \mathrm{C}$ 年代の測定結果から，500，2300$3900 ， 5000-6000 ， 9000 ， 17000 ， 35000$ 年前に 区分している。ピナツボ山周辺には，これらの噴 火による火山噴出物が泥流堆積物として数十 $\mathrm{m}$ 以 上の厚さで堆積しており, 礫層や砂層, 泥層など の互層をなしていると考えられている。また，当 地域の西部に位置する山系には, フィリピン列島 の基盤を構成する中生代-古第三紀の深成岩が露 出している。山麓の一部には新第三紀層が小規模 に分布し, 基盤岩類は平野部では沖積層に被覆さ れ, 深部に分布している（国際協力事業団・フィ リピン共和国公共事業建設省, 1993)。

1991 年 6 月 15 日に発生したピナツボ山の噴火 は 20 世紀最大級のものであり, その噴煙は高さ $17000 \sim 18000 \mathrm{~m}$ にも達し, ベトナム, マレーシ ア，シンガポールや宮古島にも降灰した（今井， 1992）。この噴火により, 山頂付近の地形は大き く変化し, 陥没による直径約 $2 \mathrm{~km}$ のカルデラが 形成されたものと推定されている。また, 火砕流

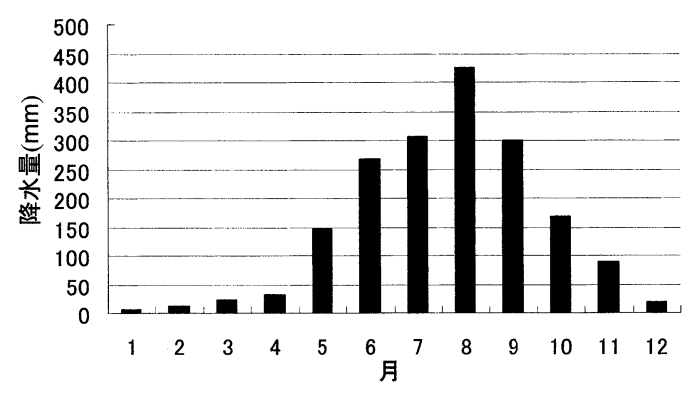

図 4 調查地域における月別降水量（1966〜 1995 年の平均值).

(Department of Public Works and Highways, Philippines, 1998 より)

Fig. 4 Monthly rainfall in study area (Average value from 1966 to 1995 ).

は火山北西部に集中し, その分布域は $100 \mathrm{~km}^{2}$ 以 上に及んだ（小屋口，1991）。1991年の噴火によ る降下火砕物の総量は約 20 億 $\mathrm{m}^{3}$, 火砕流堆積物 は 48〜 71 億 $\mathrm{m}^{3}$, さらに山頂部における山体崩壊 にともなう土砂量は約 20 億 $\mathrm{m}^{3}$ と概算されている (広瀬・井上, 1999)。

ピナツボ山周辺の気候は熱帯モンスーン気候で あり, 明瞭な乾季 $(11 \sim 5$ 月 $)$ と雨季 $(6 \sim 10$ 月）を有し，降雨の過半は雨季に集中する（図 4)。 この雨季の降雨によって火山山麓に堆積した土砂 はラハール (火山泥流)となり周辺地域を襲ったが, 特に 1994 年と 1995 年に生じた高温の Hot-Lahar (火山泥流) は多数の犠牲者を出し, その数は数百 名を超えると言われている（広瀬・井上, 1999）。

\section{2）調査地域の地形と地質}

図 5 に地形分類図を示す。調査地域の地形は山 地, 火山麓扇状地, 扇状地 (Porac 面, Pasig 面, Abacan 面), 氾濫原, 現成の三角州からなる。山 地は調查地域の西部に位置し，Porac川がその東 縁を侵食している。この山地はピナツボ山の斜面 にあたり，Porac川の支流の中小河川が侵食して 小規模な汇濫原を形成している。火山麓扇状地は 調査地域の北部に位置し, Pasig-Potrero川に よって侵食されたピナツボ山麓の谷口部に発達し ている。扇状地は調查地域の中央部に広く発達す る。平出ほか (2002) のボーリング調查の結果か 


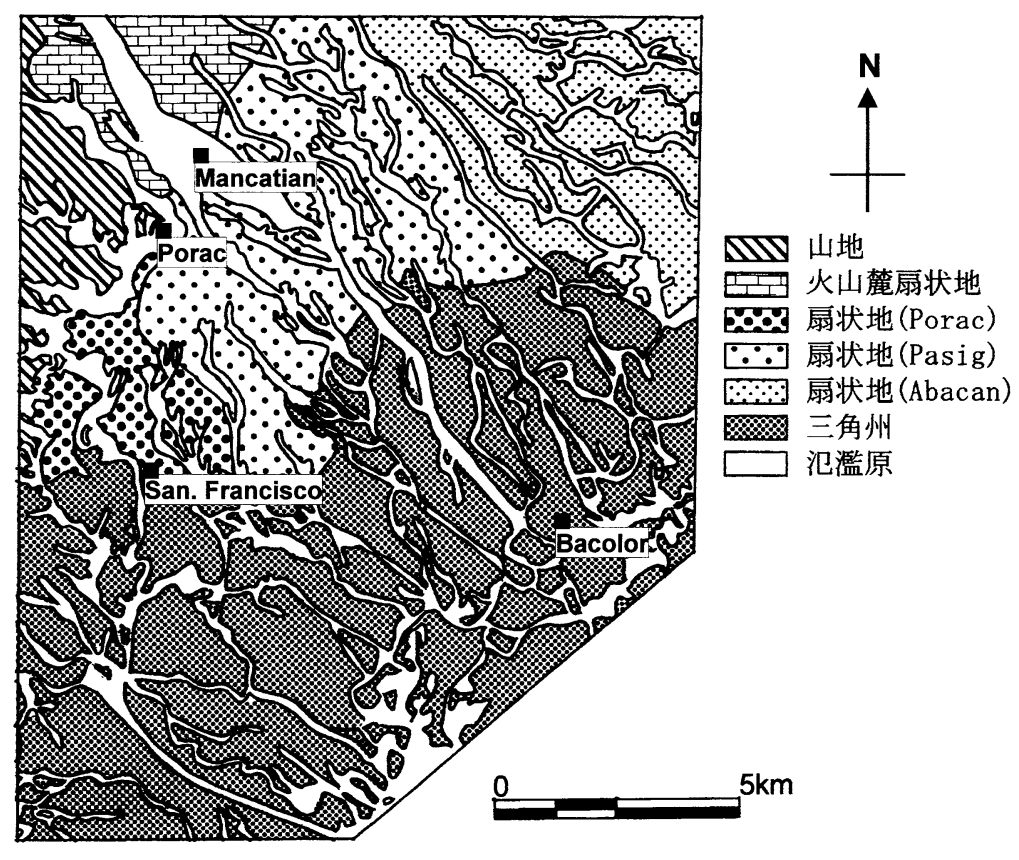

図 5 地形分類図 (噴火前).

Fig. 5 Landform classification map (before eruption of Mt. Pinatubo).

ら, 扇状地の堆積物構成は河成の砂礫を中心とす る粗粒物質からなることが明らかとなっており， 扇状地も火山麓扇状地と同様に，ピナツボ山から 供給された粗粒物質によって形成されたものと考 えられる。

一般的に，熱带では化学的風化作用が盛んなた めに，扇状地をつくるような粗粒物質が供給され にくく，扇状地が形成されにくいと考えられてい る(斉藤，1995）。このため，フィリピンは降水量 の多い変動帯に位置し，かつ国土面積が日本の約 8 割であるのにもかかわらず，扇状地を持つ河川 は日本の約 3 割弱の 129 に過ぎない（斉藤, 1994）。

しかしながら本研究の調查地域は, 河川上流に ピナツボ山を持ち，1991 年の噴火以前にも，比較 的新しい主要な噴火だけで少なくとも 6 回噴火し ているとされ（Newhall et al., 1995），粗粒物質 の供給が盛んであったために，火山麓扇状地・扇 状地が広く発達したものと考えられる。また，明 確な段丘崖は認められないものの，等高線の形態 や河川などの配置から，扇状地は隣り合った河川
がそれぞれ扇状地を形成して連続した扇状地群を なす複合扇状地（斉藤，1983）からなると考えら れる。本研究においては扇状地群と河川系の配置, および表層土壤の地域的分布から扇状地面を, Porac面, Pasig面, Abacan面の3面に区分した。

図 5 に示すように, Porac 面は Porac から下流 の Porac 川沿いに発達し, San. Francisco 付近で 三角州と連なる。またこの地形面と隣接する Pasig 面とは崖線をなさず, 地形境界は不明瞭で ある。Pasig 面は Pasig-Potrero 川沿いに発達す る扇状地であるが, Pasig-Potrero 川の周辺では 侵食が進んでいる。Abacan 面は地形面の傾斜の 状況から, Abacan 川によって主に形成されたと 考えられるが, Pasig 面と明確な崖線を形成して おらず，Pasig 面との地形境界は不明瞭である。

氾濫原は Pasig-Potrero 川やPorac 川の周辺に 形成される大規模なものと, 中小河川が扇状地面 を流下・侵食して形成する開析谷の性格を持つ中 小規模のものが扇状地面とその周辺に分布する。

三角州は扇状地の下流に分布する。平出ほか 


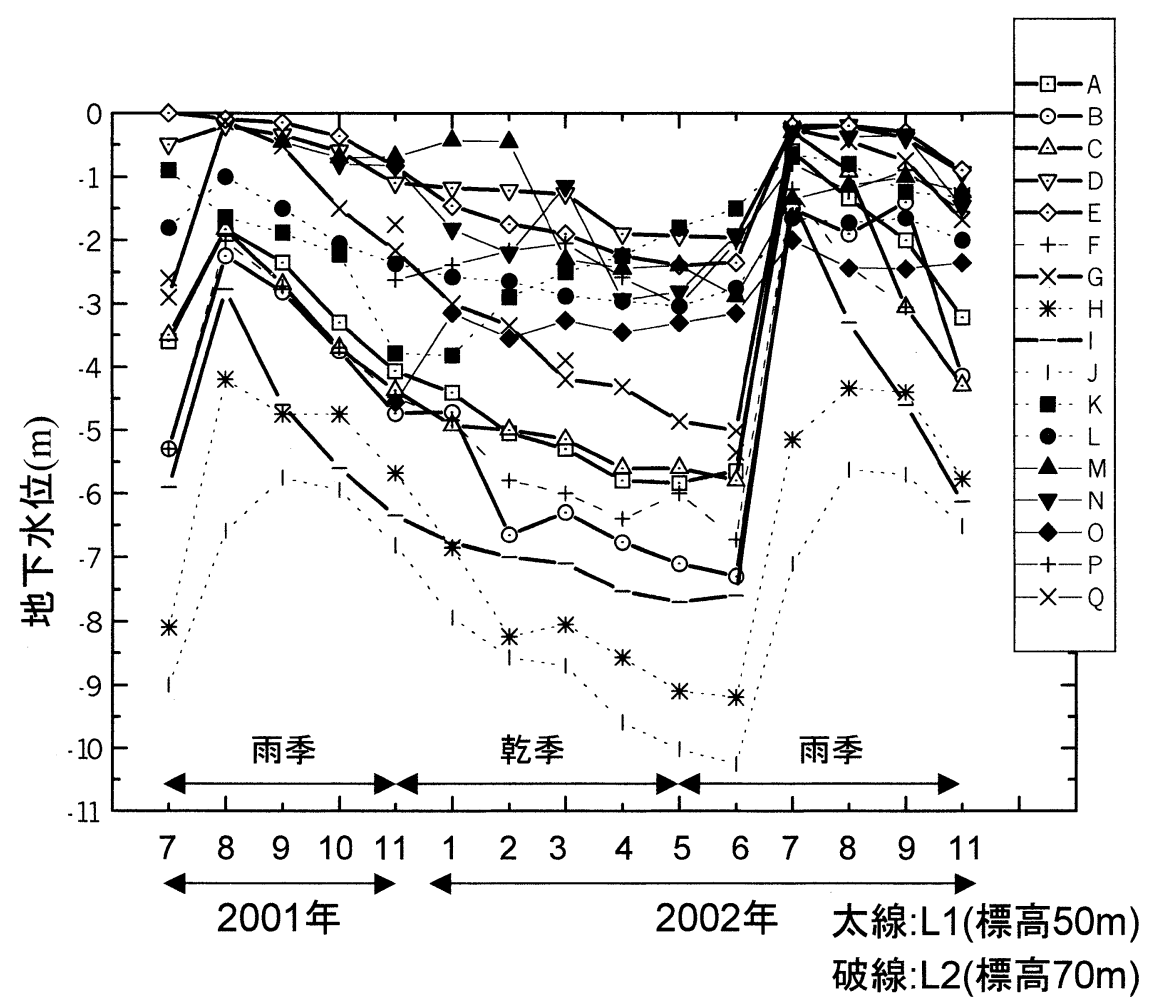

図 6 地下水位の月別変化.

Fig. 6 Monthly changes of water level.

（2001）のボーリング調査の結果から, 三角州に 位置する Bacolor においては地表から地下 $13 \mathrm{~m}$ までは新・旧ラハールが堆積し, それより下層に は海成層が堆積することが明らかとなっている。

また, 海成層中から採取されたカキの遺骸を用 いた ${ }^{14} \mathrm{C}$ 年代の測定結果から, Bacolor は約 4000 年前には浅海底であったことが示されている (平出・ホセ＝ロンダル，2002）。このことから， Newhall et al. (1995) のピナツボ山の噴火年代 に基づけば， 4000 年前から 3 回（91 年の噴火, 500，2300-3900 年前）噴火しており，これによっ て生じたラハールが浅海底に堆積して三角州が形 成されたものと考えられる。また本研究では, 約 500 年前のピナツボ火山噴火を経て, 主にPasigPotrero川などの河川による堆積・侵食作用によっ て形成されてきた地形を旧地形, Mega-Dike（巨 大堤防）やSand-Pocket（貯砂池）の建設によっ
て堤内にラハールが堆積して生じた地形を人工地 形と定義する。

\section{IV. 調査結果および考察}

\section{1）地下水位とその流向}

各地点の地下水位の月別変化を図 6 に示す。L1, L2 ともに, 観測孔における地下水位は, $7 \sim 9$ 月 (雨季) に最も高くなり，それ以降は徐々に低くな る傾向が見られた。L2に属する観測用井戸の地 下水位は 7〜9月 (雨季) にかけてそれぞれ最も 高い地下水位となり, 以降地下水位は徐々に低く なる傾向が見られた。これらの地下水位の変動は 図 4 に示した本地域における降水量の変化と対応 している。15 カ月に及ぶ観測期間には，地下水位 変動の年周期が認められた。地点によりばらつき はあるが, 地下水位は乾季から雨季にかけて急激 に上昇し，地下水位のピークを迎えてから次の雨 
表 1 地下水位の実測・推定結果.

Table 1 Measured underground water level and estimated underground water level.

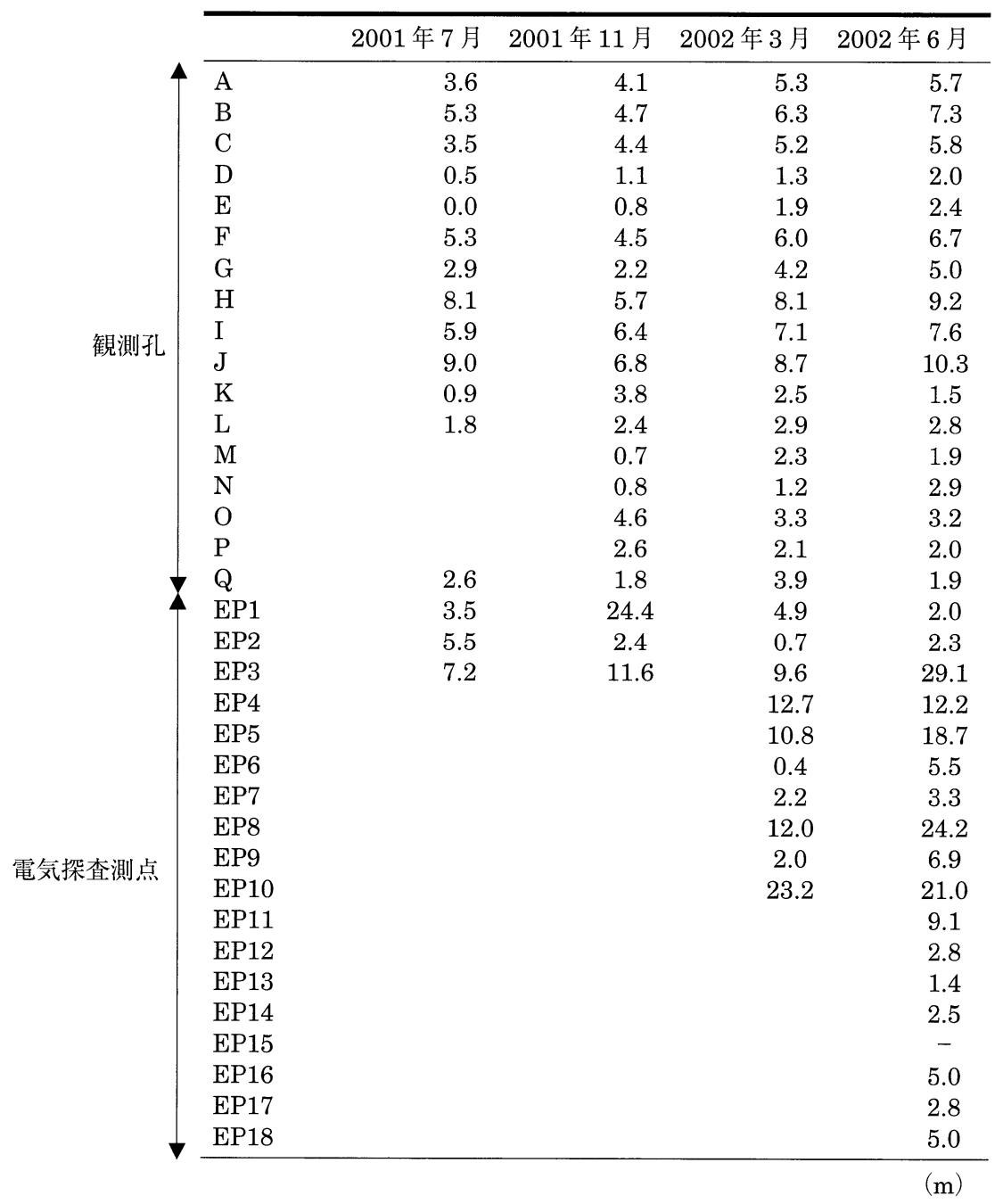

季の開始までに徐々に水位が低下していく傾向が 見られる。この観測用井戸における地下水位の測 定結果と, 電気探査法による地下水位の推定結果 （表 1）から，2001年 7, 11 月，および 2002 年 3, 6 月のデータを用いて地下水面図を作成した（図 $7 \mathrm{a} \sim \mathrm{d})$ 。電気探査法の測点数が地下水位の測定 時期により異なるため, 地下水位分布パターンの 単純な比較はできないが，Pasig-Potrero 川右岸 扇状地面（標高 $40 \sim 100 \mathrm{~m}$ ）において地下水位の 分布を比較すると, 観測時期による地下水位の空
間的分布の形状についてはほぼ差異がないことが 明らかとなった。

また, 地下水は地下水位の等ポテンシャル線に 直交する方向へ流下することを踏まえ（山本， 1983), 最も地下水位の観測点が多い 2002 年 6 月 の地下水位のデー夕をもとに地下水流向図を作成 した（図 8）。その結果より，本地域に扔ける地下 水の流動は, 以下の 3 地域に区分される。

a) Pasig グループ (グループI)

この地域においては, Pasig-Potrero 川および 

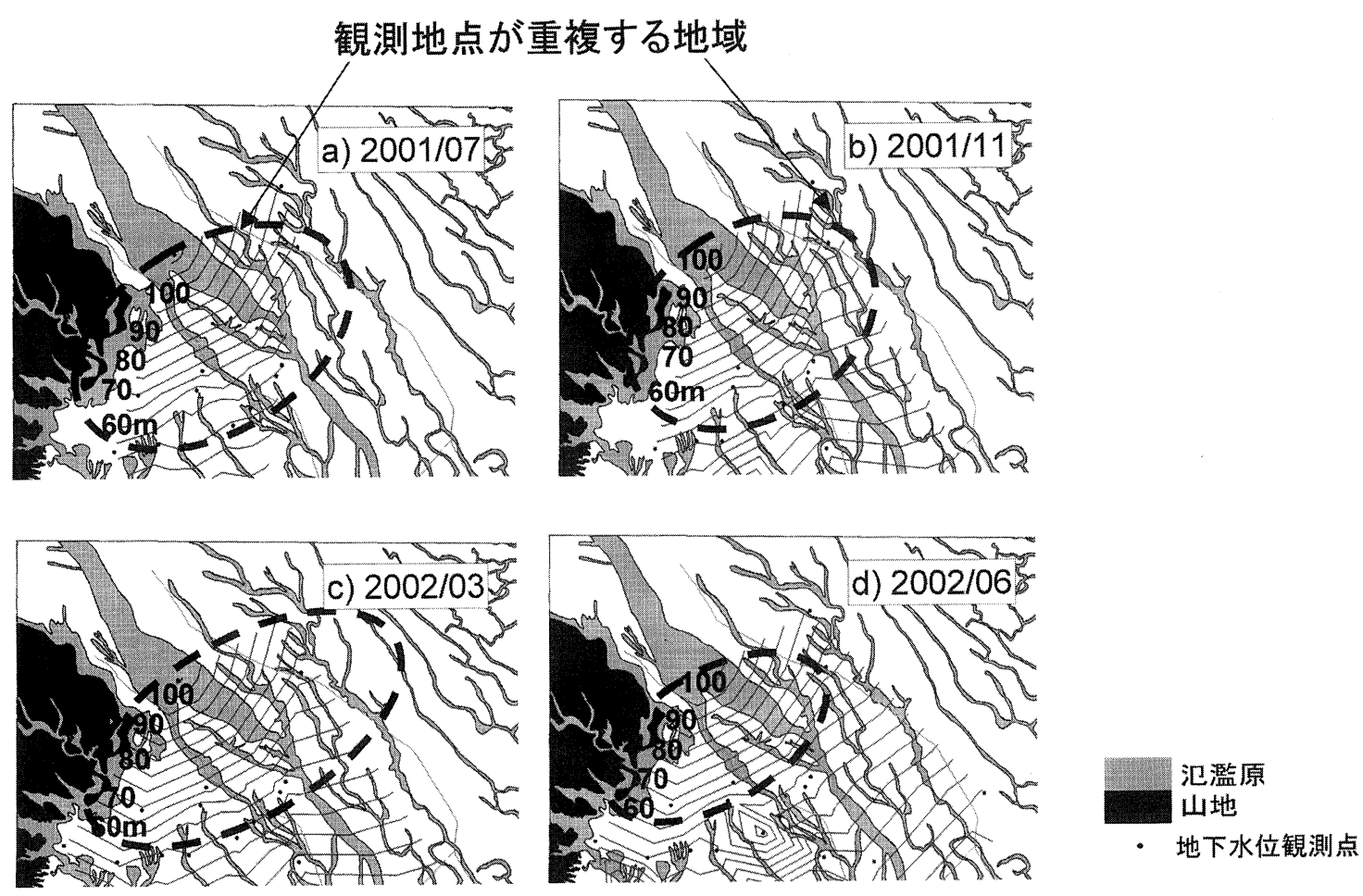

図 7 地下水位の平面的分布.

Fig. 7 Regional distribution of water level.

C4（Sanmabia creek）に地下水が流入する傾向 が見られるとともに, Site $\mathrm{P}$ 付近から下流では Pasig-Potrero川から C4 に地下水が流動する傾向 が見られる。

b）Dila-dila グループ (グループ II )

Site I 〜 EP11 〜 EP3 および Site G 〜 EP6 EP9 に地下水嶺が見られる。この地域では扇頂か ら流下してきた地下水が, Site B 付近から EP2 付近を経て流下する小河川 (C1) と Site A 付近 から EP1を経て小河川 (C2) へ流出する傾向が 見られる。また, Site I 付近から地下水が C3 (Rerital creek) と C2へそれぞれ分配されている。

c) Porac グループ (グループIII)

Site Q から EP5 付近まで地下水は, 河川と平行 に流下する一方で, EP5から EP8 付近では, Porac川に対して流下する傾向が強く見られた。 またPorac川下流では地下水位の勾配が他の地域 に比して急である。
また，地下水位観測のデータポイントが重複す る地域において，観測時期による地下水位の空間 的分布の形状にほほ差異がないことから，地下水 位の流向も季節変化を生じないと考えられる。

また，図 $7 \mathrm{a} \sim \mathrm{d}$ に見られるように，いずれの地 下水位観測時においても, 先端部で地下水位は汇 濫原付近で低くなる傾向が見られた。

以上地下水流動の把握の結果から, 地下水位は Sand-Pocket の周辺で, 傾きが異なることが明ら かとなった。この要因として, Sand-Pocket 内へ のラハールの堆積にともなう天井川化の影響が考 えられた。そこで Sand-Pocket周辺と, PasigPotrero 川の中流域（標高 $50 \mathrm{~m}$ 付近）において測 量を実施し, Mega-Dike 堤内外の比高を求めた。 地形測量にあたっては, レーザーによる測量を 行った。図 9aにSand-Pocket 周辺で行った測量 の結果を示す。この図の等高線形状からわかるよ うに, Sand-Pocketの周辺では比高が大きく, 標 


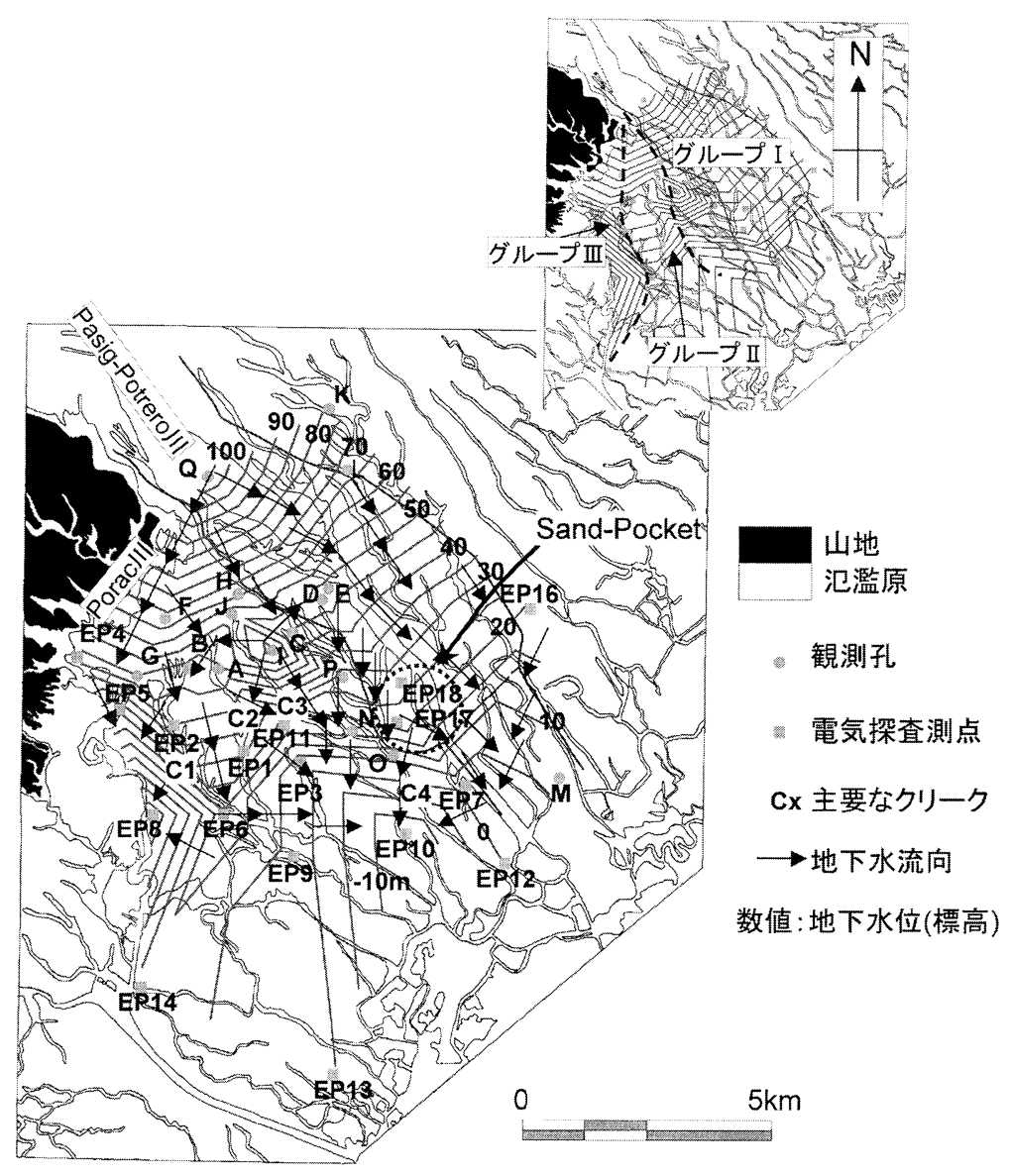

図 8 地下水流向図 (2002 年 6 月).

Fig. 8 Underground water flow (Jun 2002).

高 $30 \mathrm{~m}$ 以上の Pasig-Potrero 川中流域では比高 が小さいことがわかる。図 9bにSand-Pocket 周 辺における横断面図を示すが, Mega-Dike の堤内 外で比高が最大約 $12 \mathrm{~m}$ と大きく, なおかつ河道 から Mega-Dike 方向へ標高が低下していること がわかる。このことから, Sand-Pocket の周辺で は, 河川から堤内地へ地下水が流下しやすい環境 にあると言える。また, 測量で得られた SandPocket 周辺の等高線と地下水の等位線を比較す ると, 地下水には地形面の影響が大きいことがわ かる。すなわち, ラハールの堆積をほぼ受けない Mega-Dikeの堤内地では地下水は旧地形の谷線 に沿って流動し(図 $7 \mathrm{a} \sim \mathrm{d}$ ), ラハールが厚く堆
積した Sand-Pocketの周辺では, 地下水が归地形 とは異なる流動を示す傾向が明らかとなった。

\section{2）地下水涵養域の季節変化}

図 10 に標高別地下水位の月別変化を示す。この 戝に見られるように 2001 年の地下水位変動では, Pasig-Potrero 川中流に位置する Site C, Hにおい ては 2001 年 8 月に地下水位が最も高くなるのに 対し，より下流に位置するSite N, O, Pでは 2002 年 7 月に地下水位が最も高くなった。扇頂部にお いて河川により涵養された地下水は, その流下に ともなって扇央, 扇端部の地下水位にも影響を与 えるものと考えられる。

そこで, Site C (標高 $50 \mathrm{~m}$ ), P (標高 $30 \mathrm{~m}$ ) 
a)
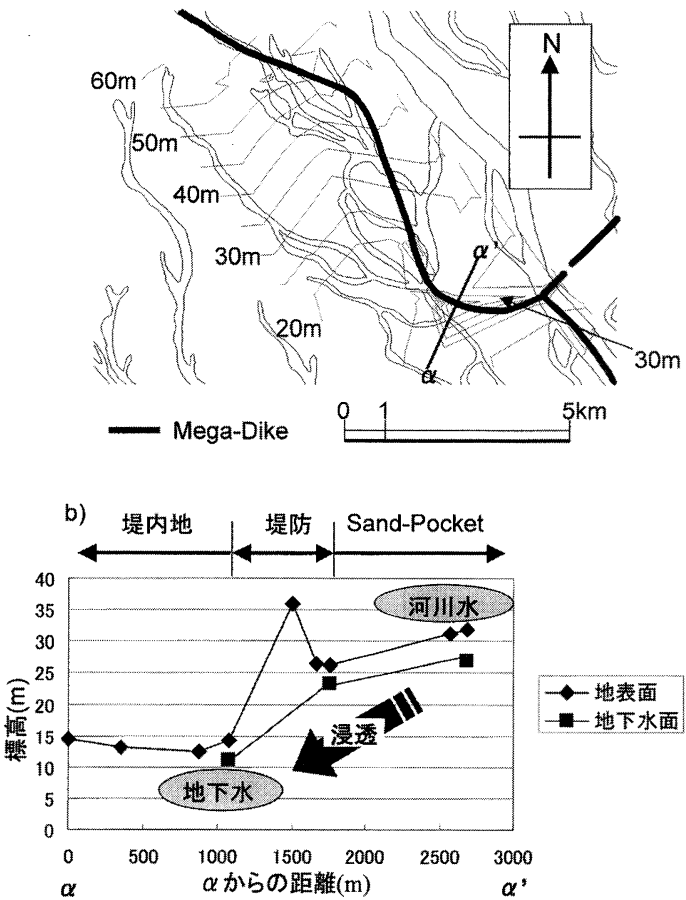

図 9 Sand-Pocket 周辺における地形測量結果. a) 測量に基づく等高線図，b）横断面図

Fig. 9 Results of survey around Sand-Pocket. a) Contour map by survey (Jun 2002), b) Cross section between inside and outside of Mega-Dike.

間における地下水の理論上の移動速度を算出し， 上述の Site C, P 間における地下水位のピーク移 動の時間的差異との整合性を検討した。

帯水層の粒度に基づいて求められる Creager の 透水係数 $K$ および動水勾配 $I$ を用いて, 以下の夕゙ ルシーの公式から, 地下水の見掛けの流速 $v$ $(\mathrm{cm} / \mathrm{s})$ を計算することが可能である。

$$
v=K I
$$

ここで, $K$ : 透水係数 $(\mathrm{cm} / \mathrm{s}), I$ : 動水勾配（定 数)である。

本地域の表層地質は主に Angeles sand series や La Paz sand seriesなどの砂礫からなり（Teodomero, 1956), Creagerの実験式によれば, 粗 粒砂の透水係数は $1.1 \times 10^{-1} \sim 3.6 \times 10^{-1} \mathrm{~cm} / \mathrm{s}$,
細礫の透水係数は $1.8 \mathrm{~cm} \times 100 / \mathrm{s}$ である（河野， 1989）。また，Site C，P間の動水勾配は 11.1\%。 であることから，これらを $K ， I$ としてそれぞれ （1）式に代入して，地下水の見掛けの流速 $(\mathrm{m} /$ 月 に換算）を計算した。その結果, 粗粒砂で $31.6 \mathrm{~m} /$ 月〜 $103.6 \mathrm{~m} /$ 月，細礫で $517.9 \mathrm{~m} /$ 月となった。 Site $\mathrm{C}, \mathrm{P}$ 間の距離は約 $2.2 \mathrm{~km}$ であるから，上記 の見掛けの流速に基づいて Site Cから Site Pまで の地下水の到達時間を計算すると，粗粒砂で 21.2 〜 69.6 力月, 細礫で 4.2 力月となる。観測孔にお ける実測值では，Site C，P間における地下水位 のピークの時間的ずれは 11 カ月であり, 計算で得 られた砂礫層における地下水到達時間, $4.2 \sim 21.2$ カ月の範囲内となっている。このことから，地下 水位のピークの変化が地下水移動を反映している 可能性が示唆される。この結果の妥当性を検討す るため，調查地域に扔いて揚水試験を実施し，水 理係数の把握を行ったうえで見掛けの流速を算出 した。

揚水試験は, 2002 年 11 月に, Pasig-Potrero 川流域に位置する Site C において実施した。揚水 試験は河野（1989）が示す手順に準じて行い，現 地で農業や魚養殖に一般的に用いられる最大揚水 量の大きいエンジン式ポンプを用いた。なお，揚 水試験に用いた揚水井, 観測井は図 11 に示すよう に設置した。観測井 No.0 には直径 $5 \mathrm{~mm}$ の孔が $1 \mathrm{~m}$ あたり 200 個貫孔された塩化ビニル製の孔明 管を井戸の全哚度にわたって，No.1〜No.3には 金属製パイプを井戸上部に，金属製のスクリーン を井戸下部に挿入した。

図 12 に揚水試験結果と透水係数の計算結果を 示す。透水係数は $5.78 \times 10^{-2} \sim \times 9.02 \times 10^{-2}$ $\mathrm{cm} / \mathrm{s}$ となり, 先に示した粗粒砂の透水係数 $1.1 \times$ $10^{-1} \sim 3.6 \times 10^{-1} \mathrm{~cm} / \mathrm{s}$ と近い值となっている。 一方, 貯留係数は $10^{-4} \sim 10^{-6}$ と小さい值を示した が，不圧地下水において貯留係数は一般的に $1 \times$ $10^{-1} \sim 1 \times 10^{-2}$ とされており，この值と適合しな い。山本 (1983) は理論上貯留係数を求めること は可能であるが，実測值からそれを求めることは 困難であると指摘している。おそらく，本研究に おける揚水試験はポンプの能力から貯留係数の計 


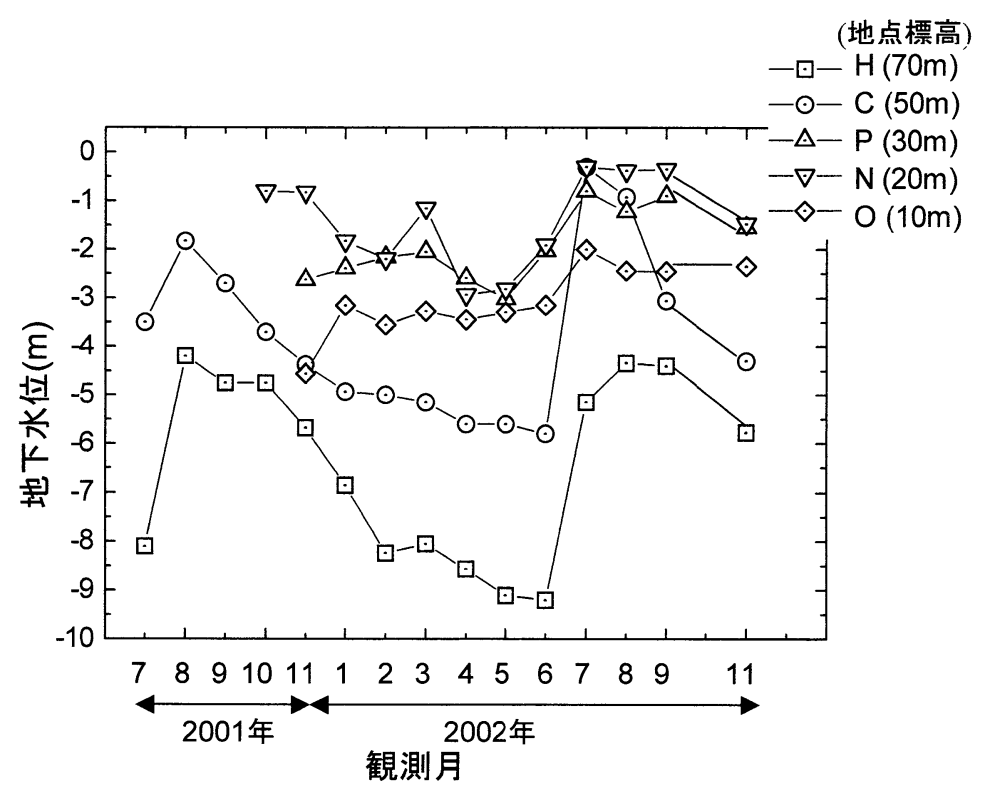

図 10 地下水位の変化 (標高別).

Fig. 10 Changes of underground water level (by elevation).

算の基礎となる揚水時間が短いため, 計算上の誤 差が生じたものと考えられる。よって実流速では なく見掛けの流速を用いて地下水の移動を考えた 場合，扇状地における地下水の流速は，地層がほ ぼ粗粒砂からなると仮定して, 透水係数を均一に 扱っても良いと判断した。

また地下水位の地形との関連性から，地下水の 涵養源と地形との関連についても考察が可能であ る。嶋田（1998）は扇状地河川の地下水涵養につ いて, 河川による地下水涵養は線による涵養であ るのに対して，扇状地面は面による涵養であるた め, 扇状地の地下水の多くは扇状地面からの浸透 であり, 河川からの地下水涵養は小さいと指摘し ている。しかし, 本研究の調査地域は, 扇状地面 がその両端を Pasig-Potrero, Poracの両河川に よって侵食されていることに加え, 乾季に降水が ほぼないことから, 地下水涵養の季節的差異が生 じる要因として河川水の寄与が大きいと考えられ る。そこで河川水の地下水への浸透が大きいと仮 定し, 本地域における地下水涵養形態を以下のよ うに考察した。山本 (1983) は扇状地の地下水形 態として, I . 扇頂涵養帯, II a. 扇央不圧水帯,
II b. 扇央被圧水帯， III. 扇端湧泉帯に区分し， それぞれについて地下水の形態について考察を 行っている。本地域は地質が扇状地堆積物起源の 未固結砂礫層を中心とすることから, 被圧水帯は 存在しないと考えられるため, 山本の区分のうち I， II a， III 利用して地下水形態を検討する。 雨季には河川から地下水が扇頂涵養带に涵養さ れる一方で，それより下流に位置する扇央不圧水 带, 扇端湧泉帯では, 河川からの地下水の涵養が 行われず，地下水位が低下するものと考えられる。 これに対し雨季末期から乾季にかけては，河川か らの扇頂涵養帯に対する地下水の涵養が減少する 一方で，雨季に扇頂涵養带へ涵養された地下水が 下流へと流出し，下流の扇央不圧水帯および扇端 湧泉帯に涵養されるものと考えられる。

上述の地下水涵養域の移動について検討を行う ため, 地下水位変動量の空間分布を図 $13 \mathrm{a}, \mathrm{b}$ に 示す。なおこの図は地下水変動量を議論するため, 観測孔のデータのみを用いて作成した。その結果， 雨季の間（2001 年 7 月〜 11月）では，扇頂から 扇央と扇状地西部では地下水位が $0.6 \sim 2.2 \mathrm{~m}$ 上 昇する一方で, Pasig-Potrero 川周辺と扇状地東 
a)

\begin{tabular}{ccc}
\hline 揚水量 $\left(\mathrm{cm}^{3} / \mathrm{s}\right)$ & 揘水時間(分) & 揚水井 \\
\hline 4000 & 30 & No. 0 \\
\hline
\end{tabular}

b)

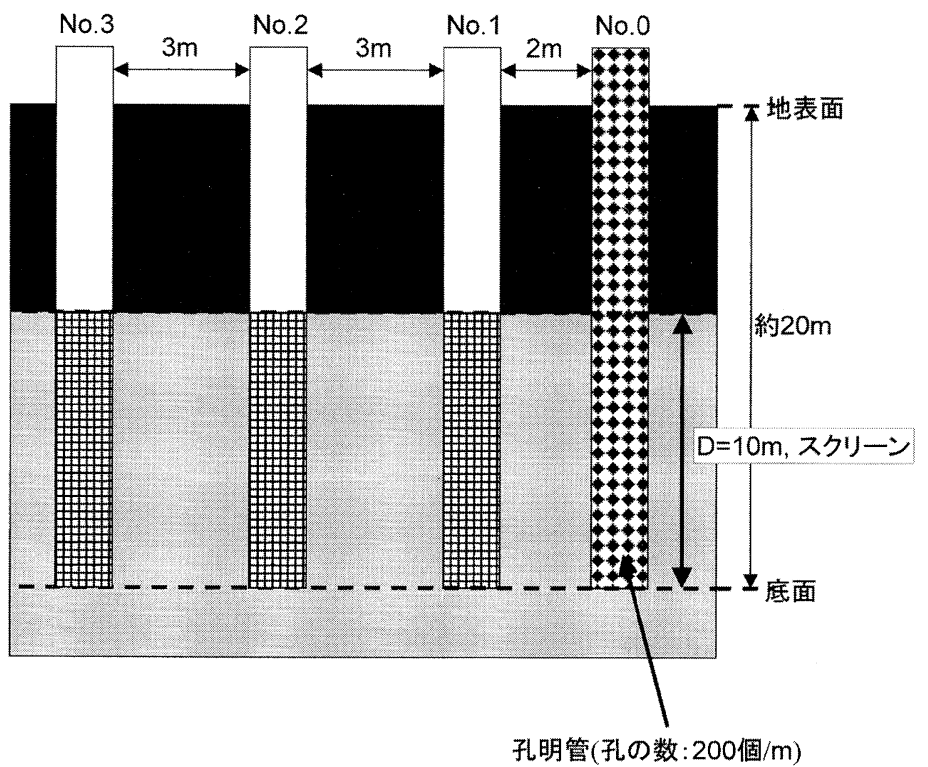

図 11 揚水試験の仕様と井戸配置.

a）揚水試験の仕様， b）揚水試験の井戸配置

Fig. 11 Specification and arrangement of well for pumping test.

a) Specification of pumping test, b) Arrangement of well for pumping test

a)

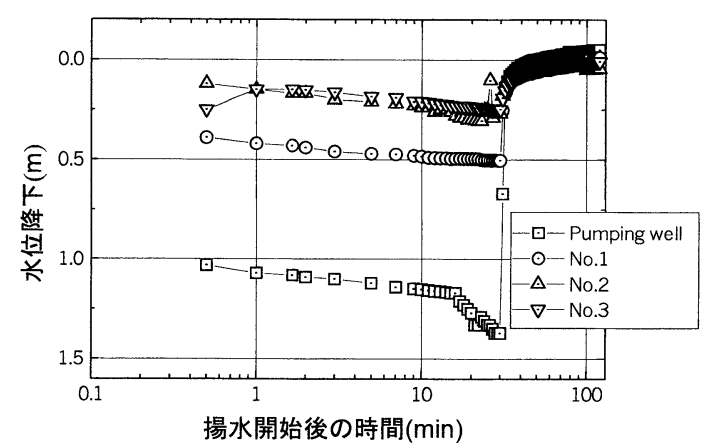

b)

\begin{tabular}{lll}
\hline 分析対象 & Jacob法 & 回復法 \\
\hline 既存井戸 & & \\
No.1 & $9.02 \times 10^{-2}$ & $5.78 \times 10^{-2}$ \\
No. 2 & $8.14 \times 10^{-2}$ & $6.81 \times 10^{-2}$ \\
No.3 & $8.68 \times 10^{-2}$ & $5.84 \times 10^{-2}$ \\
\hline
\end{tabular}

$(\mathrm{cm} / \mathrm{s})$
図 12 揚水試験結果と透水倸数の分析結果.

a) 揚水試駼結果（2002 年 11 月）

b）透水試験の分析結果

Fig. 12 Results of pumping test and calculation of permeability.

a) Results of pumping test (Nov 2002)

b) Analytical results of permeability by pumping test 


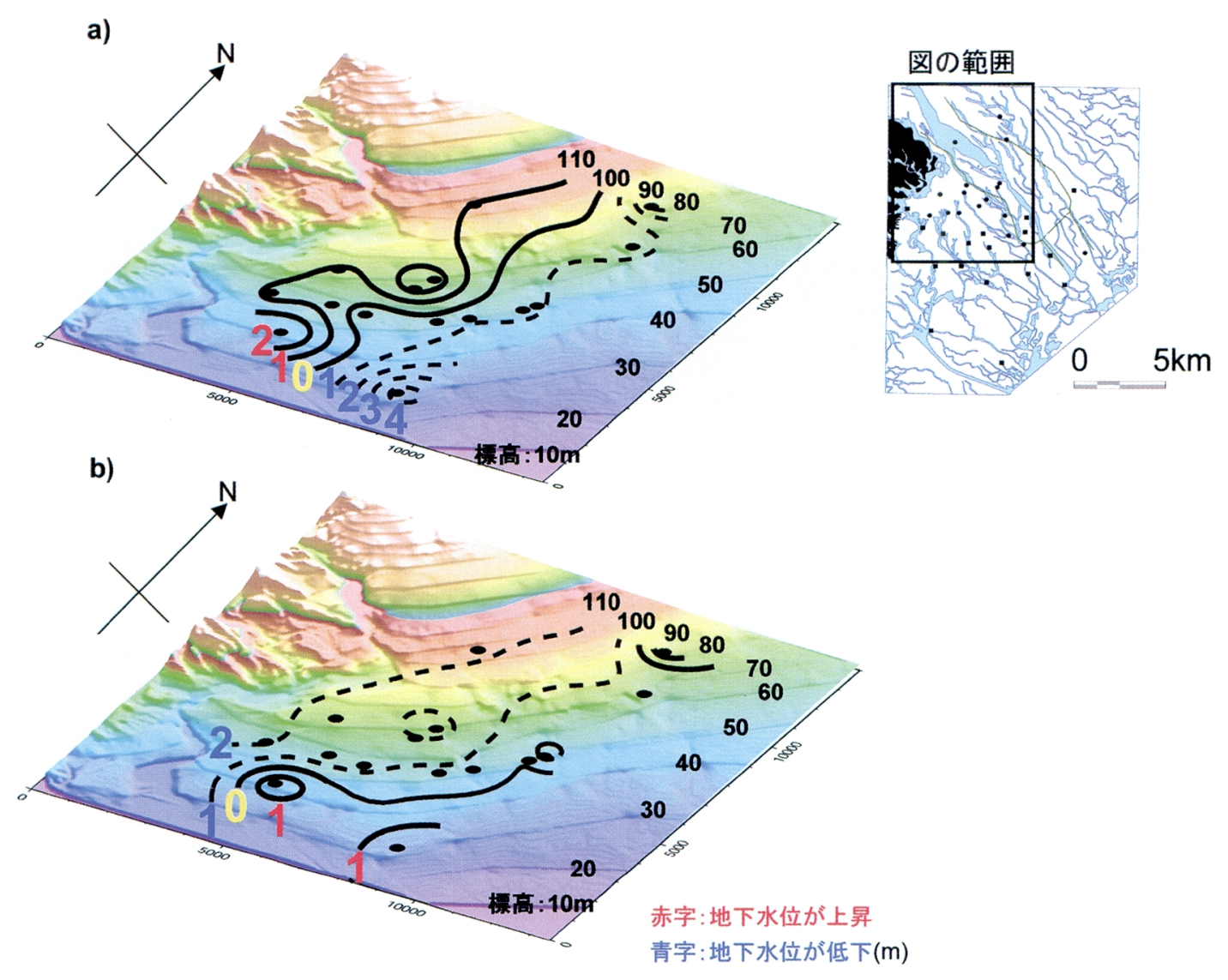

図 13 地下水位変化量の地域分布.

a）地下水位の増減（雨季, 2001/11 の地下水位～2001/07 の地下水位).

b）地下水位の増減（乾季，2002/03 の地下水位～2001/11の地下水位).

Fig. 13 Regional distribution.

a) Changes of underground water level (Rainy season, Underground water level of Nov 2001-Underground water level of Jul 2001).

b) Changes of underground water level (Dry season, Underground water level of Mar 2002-Underground water level of Nov 2001).

部では地下水位が $0.5 \sim 4.4 \mathrm{~m}$ 低下する傾向が見 られた。一方，雨季明け（2001 年 11 月）から乾 季（2002 年 3 月）にかけては，扇頂から扇央にお いて地下水位が $0.2 \sim 2.4 \mathrm{~m}$ 低下し, 扇端付近で 地下水位が $0.6 \sim 1.3 \mathrm{~m}$ 上昇した（表 2 ）。研究地 域に㧍ける年平均降水量は $1963 \mathrm{~mm}$ (Clark 空軍 基地, 1945-1983 年平均) (Department of Public Works and Highways, Philippines, 1998) であ る一方で, 年平均可能蒸発量は $1643 \mathrm{~mm}$ であり, 年平均から算出される地下水の涵養量は $320 \mathrm{~mm}$
となるが, 調查地域における乾季の降雨量は極め て少なく蒸発量も多いと考えられることから, 天 水による地下水の涵養は雨季に集中するものと考 えられる。小野寺 (1996) は夕ンザニアの半乾燥 地域において, 月間の可能蒸発散量と月別降水量 との比較から水収支計算を行っているが，集中的 な降雨があれば半乾燥地域においても降雨による 地下水涵養の可能性があると指摘している。本地 域では四 13 で示されたように, 地下水位が乾季か ら雨季にかけて急激に上昇していることから，小 
表 2 地下水位の変化.

Table 2 Changes of underground water level.

\begin{tabular}{lrrr}
\hline site & 標高 & $2001 / 07 \rightarrow 11$ & $2001 / 11 \rightarrow 2002 / 03$ \\
\hline Q & 110 & 0.9 & -2.2 \\
A & 50 & -0.5 & -1.2 \\
B & 50 & 0.6 & -1.6 \\
C & 50 & -0.9 & -0.8 \\
D & 50 & -0.6 & -0.2 \\
E & 50 & -0.8 & -1.1 \\
G & 50 & 0.7 & -2.0 \\
I & 50 & -0.4 & -0.8 \\
F & 70 & 0.8 & -1.5 \\
H & 70 & 2.4 & -2.4 \\
J & 70 & 2.2 & -1.9 \\
K & 70 & -2.9 & 1.3 \\
L & 70 & -0.6 & -0.5 \\
P & 30 & & 0.6 \\
N & 20 & & -0.3 \\
O & 10 & & 1.3 \\
\hline & & & $(\mathrm{m})$
\end{tabular}

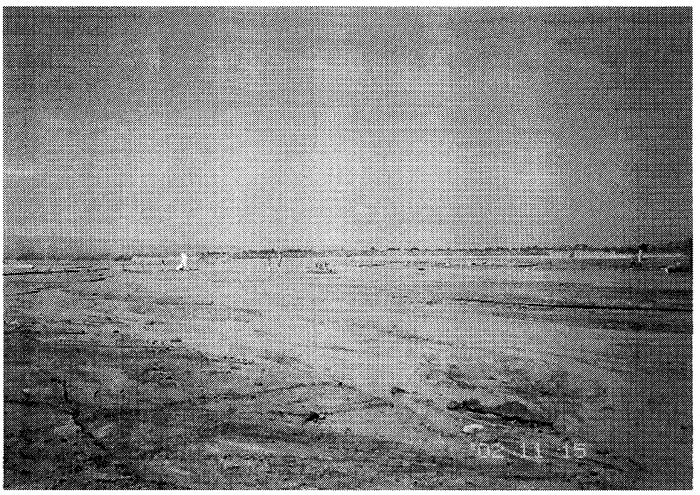

写真 1 Pasig-Potrero 川における掃流の状況.

Photo 1 Condition of traction in Pasig-Potrero river.

野寺（1996）と同様に雨季に天水による集中的な 地下水の涵養が生じているものと考えられる。

また，これらの結果から，地下水の涵養域は季 節変化を生じるとともに, 山本（1983）から考察 した，扇状地の涵養域移動の形態は, 調查地域に おける実際の地下水移動においても認められた。

3）地下水質の地域分布と季節変化

a）水質組成型の地域分布

Pasig-Potrero 川と Porac 川はいずれもピナツ

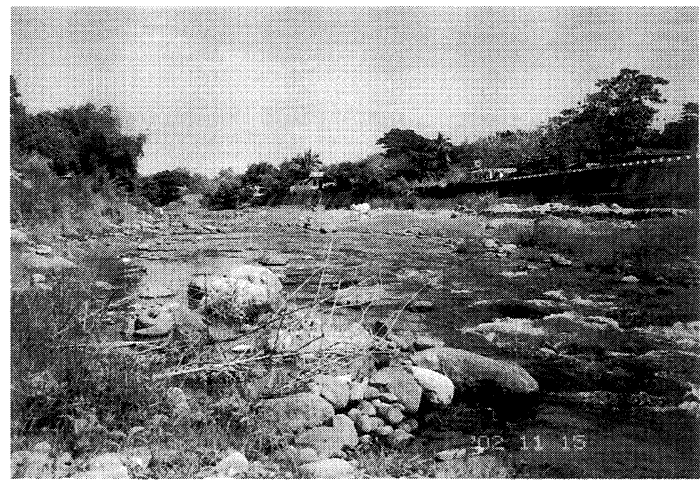

写真 2 Porac 川における掃流の状況.

Photo 2 Condition of traction in Porac river.

ボ山麓を源とする河川であるが，上流部における ラハールの堆積環境がそれぞれ大きく異なり，掃 流の状況に大きな差異が生じている（写真 $1 ， 2 ） 。$ このため, 河川の水質は流域によって大きく異な ると考えられる。さらに調査地域は Pasig-Potrero 川と Porac 川に囲まれ，河川の水質は地下水質に 強い影響を与えていると推察される。

Hendry and Schwartz(1990)はカナダの Milk riverに拈いて, Gosselin et al.（2001）はアメリ 
カの Great plains において, それぞれ調査対象地 域における主要イオン $\left(\mathrm{Ca}^{2+}, \mathrm{Mg}^{2+}, \mathrm{Na}^{+}, \mathrm{K}^{+}\right.$ $\left.\mathrm{SO}_{4}{ }^{2-}, \mathrm{Cl}^{-}, \mathrm{HCO}_{3}{ }^{-}\right)$の水質組成の地域分布と地 質の関係から，地下水質の形成過程について考察 を行っているが，本研究の調査地域における地質 構成はほぼ Pasig-Potrero 川や Porac 川などの砂 鿬を中心とする河成堆積物からなり，地質の差異 による地下水質への影響は小さいと考えられるこ とから, 地下水質の地域分布は, その地下水の供 給源に大きく影響されるものと考えられる。図 14 に 2001 年 7 月〜 2002 年 6 月に調查地域の河川水 および既存の井戸から採取した水の水質組成型を トリリニア・ダイアグラムで示す。

水質組成型には I : $\mathrm{Ca}\left(\mathrm{HCO}_{3}\right)_{2}$ 型（河川水や 浅い地下水), II : $\mathrm{NaHCO}_{3}$ 型（淡水性の被圧地 下水), III $: \mathrm{CaSO}_{4}, \mathrm{CaCl}_{2}$ 型, $\mathrm{IV}: \mathrm{Na}_{2} \mathrm{SO}_{4}$ 型 (海 水, 化石塩水, 温泉, 坑内水等) などが存在する (山本, 1983)。

本地域に扔ける地下水の水質組成型は図 14 に 示すように季節によって異なる。2001 年 7 月 (雨 季）と 2002 年 3 月 (乾季), 6 月 (雨季) の地下 水は $\mathrm{CaSO}_{4}$ 型と $\mathrm{Na}_{2} \mathrm{SO}_{4}$ を示す。これに対して 2001 年 11 月は水質組成型が分散し, 全ての水質組 成型を示す。この要因としては，2001年 11 月に $\mathrm{HCO}_{3}$-濃度が上昇することがあげられる。

また調査地域の水質組成型はサンプリング地点 が最も多い 2002 年 6 月の水質組成を用いると, 3 つのグループに大別できる。

$\mathrm{A}$ ：三角州タイプーこの水質組成型には三角州 の井戸が属し, $\mathrm{CaSO}_{4}, \mathrm{CaCl}_{2}$ 型および $\mathrm{Na}_{2} \mathrm{SO}_{4}$ に 広く分布する。また他の水質サンプルと比較して, 高い $\mathrm{Mg}^{2+}$ 濃度を示す。

$\mathrm{B}$ ：扇状地夕イプーこの水質組成型には扇状地 の井戸が属し, $\mathrm{NaHCO}_{3}$ 型を示すが, やや $\mathrm{CaSO}_{4}$, $\mathrm{CaCl}_{2}$ 型の分布を示す。

$\mathrm{C}$ ：Porac川タイプーこの水質組成型には Porac 川のサンプルが属し, $\mathrm{CaSO}_{4}, \mathrm{Na}_{2} \mathrm{SO}_{4}$ 型を示す が，やや $\mathrm{NaHCO}_{3}$ 型寄りの分布を示す。

D：Pasig-Potrero 川タイプーこの水質組成型 にはPasig-Potrero 川のサンプルが属し, $\mathrm{NaHCO}_{3}$ 型を示す。 2002 年 6 月の水質組成は 2002 年 3 月
の水質組成と比べると, 各タイプの分布が拡散し ていることがわかる。この要因としては主に， 2002 年 6 月 (雨季) には, 2002 年 3 月 (乾季) と比較して $\mathrm{Ca}^{2+}$ の割合が上昇したことが考えられ る。ピナツボ山に源を有する Pasig-Potrero 川の サンプルの水質型と, $\mathrm{Ca}^{2+}$ の割合が 3 月と 6 月で 大きく変化していることからも, 降雨によってピ ナツボ山周辺の $\mathrm{Ca}^{2+}$ イオンが地下水抢よび河川水 に $\mathrm{Ca}^{2+}$ イオンが溶出したことがその要因として考 えられる。伊藤・山田（1996）は圑場試験を行っ て, 降水によるピナツボ山起源のラハール土壌の 塩基溶脱について考察を行っているが, 塩基の中 では $\mathrm{Ca}^{2+}$ が最も多く溶脱すると指摘している。

また, 2001 年 11 月と 2002 年 3,6 月の水質組 成を比較すると, 乾季の 2002 年 3 月では $\mathrm{CaSO}_{4}$, $\mathrm{CaCl}_{2}$ 型および $\mathrm{Na}_{2} \mathrm{SO}_{4}, \mathrm{NaCl}$ 型に水質組成が偏 在するが, 雨季が終わる 2001 年 11 月の水質組成 は河川水の寄与が増大して $\mathrm{I} \sim \mathrm{N}$ の全ての水質組 成型を示す。特に $\mathrm{HCO}_{3}$ の割合の季節变化が大き く, $\mathrm{HCO}_{3}{ }^{-}$の割合増加が水質組成型の変化に大き な影響を与えている。

またいずれの観測時期においても, 各地点とも

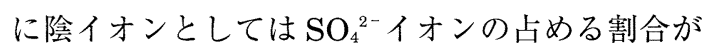
高い。森ほか（1990）は, インドネシアのバリ島 において上流に火山湖を有する河川の水質につい て言及しているが，その場合においても河川の $\mathrm{SO}_{4}{ }^{2-}$ イオン濃度がとくに高いことを示しており, I 章で述べたような火山に起源を有する硫黄分が, 調查地域においても河川水・地下水に溶出・流入し, $\mathrm{SO}_{4}{ }^{2-}$ が高濃度となっていると考えられる。

b) $\mathrm{SO}_{4}{ }^{2-}$ イオンの地域分布

図 $15 \mathrm{a} \sim \mathrm{d}$ に, 2001 年 7,11 月および 2002 年 3,6 月の $\mathrm{SO}_{4}{ }^{2-}$ イオンの空間分布を示す。 1000 $\mathrm{ppm}$ を超す $\mathrm{SO}_{4}{ }^{2-}$ イオンの高濃度域は 2001 年 7 月 および11月にPasig-Potrero川流域に見られるが, 2002 年 3 月には見られない。また $\mathrm{SO}_{4}{ }^{2-}$ イオンが 最も高濃度を示す区域はいずれの時期においても, Pasig-Potrero 川周辺に分布することが明らかと なった。

サンプリング地点が最も多い 2002 年 6 月にお ける $\mathrm{SO}_{4}{ }^{2-}$ イオンの分布と, $\mathrm{IV}-1$ ) で明らかになっ 

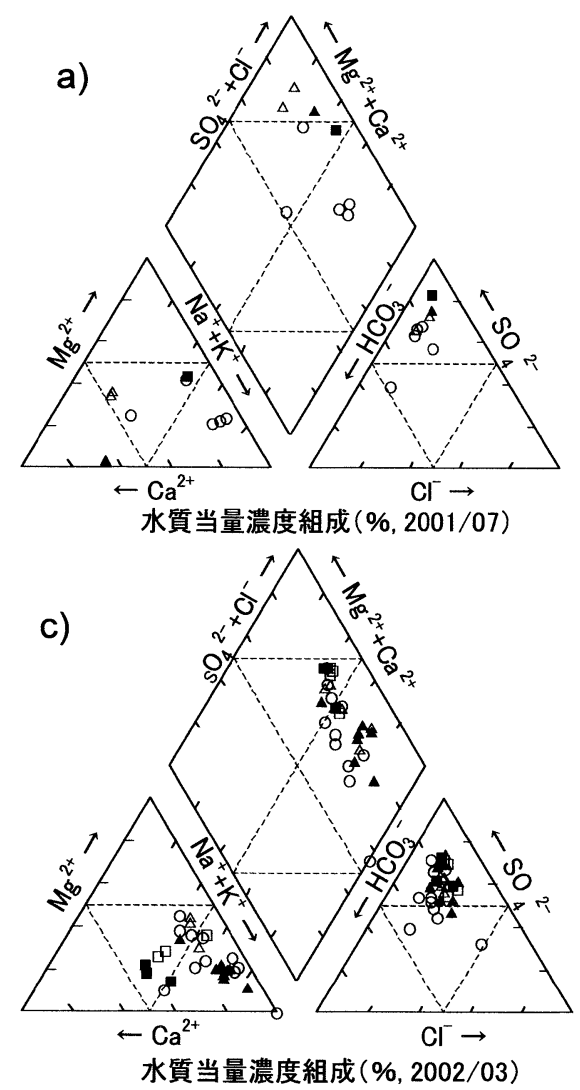
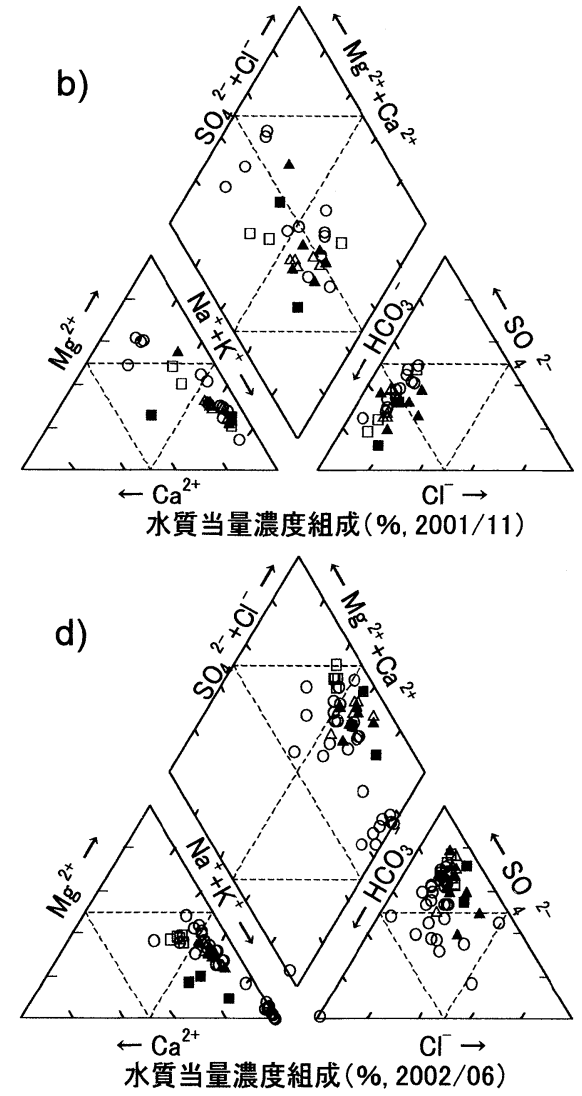

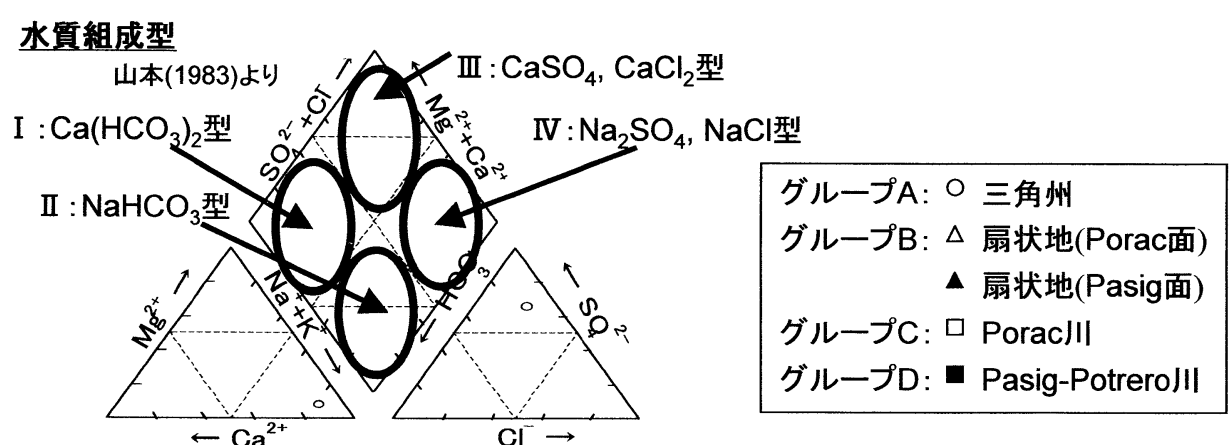

四 14 水質組成の分布 (2001 年 7 月 2002 年 6 月).

Fig. 14 Ion component of water samples (Jul 2001-Jun 2002).

た地下水の流向を重㸚て見ると（図 $16 ）, \mathrm{SO}_{4}{ }^{2-}$ イ オンの濃度分布, 特に $1000 \mathrm{ppm}$ を超す高濃度域 が流向に沿って分布していることがわかる。

Imai et al.（1993）や吉田・太田（2002）が指 摘したように, 調查地域にはピナツボ山の噴火に
よって供給された多量の硫黄分が，ラハールや火 山灰中に存在している。降雨によって洗脱されや すい硫黄分は，有珠山と浅間山の火山灰を用いて 过（1986）が示したのと同様に，降雨により硫黄 分が河川水や地下水に溶出しているものと考えら 

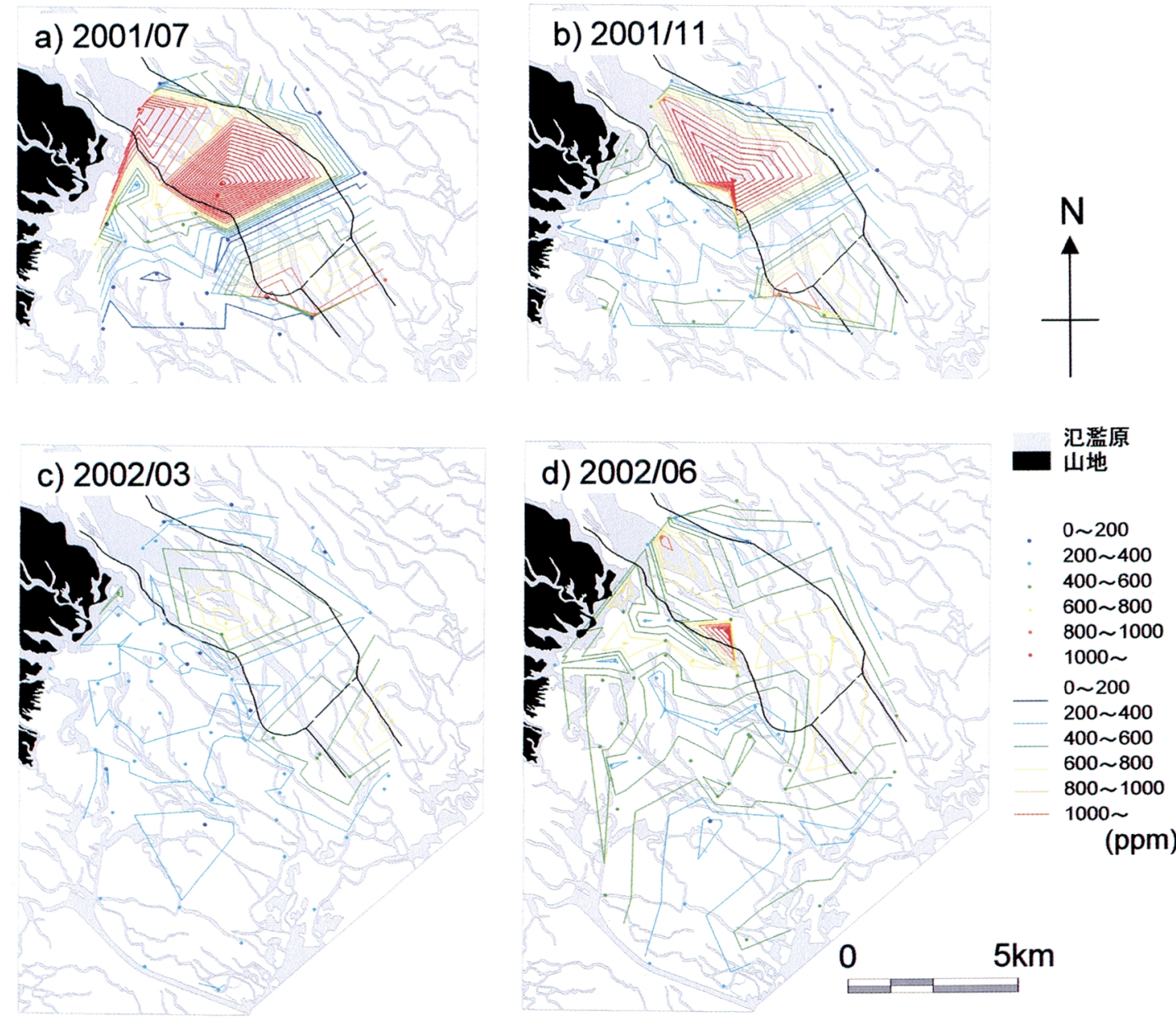

図 $15 \mathrm{SO}_{4}{ }^{2-}$ イオンの地域分布と季節変化.

Fig. 15 Regional distribution of $\mathrm{SO}_{4}{ }^{2-}$ ion and seasonal changes of $\mathrm{SO}_{4}{ }^{2-}$ ion concentration.

れる。調査地域は Pasig-Potrero 川と Porac 川に 囲まれ，浅層地下水は両河川の域外から流入せず， かつIV-1）で明らかになったように，河川から地 下水への浸透は Pasig-Potrero 川によるものが大

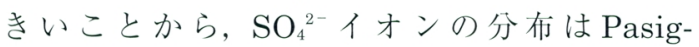
Potrero川の河川水の地下水への浸透と, 分配経 路を示しているものと推察される。

\section{V. 地下水質の形成過程モデル}

これまで述べてきたように地下水流動および地 下水質の地域的偏在性から, 以下の PasigPotrero 川を中心とする地下水質の形成過程モデ
ルが推察された(図 17)。ピナツボ山の噴火によっ て放出された火山性物質は河川水中に溶出するた め，Pasig-Potrero 川には高濃度のイオンを含む 河川水が流れる。河川水は河床より鉛直方向と水 平方向に浸透するが，河床が下刻されている，も しくはほぼ同じ標高である場合には，河川水の水 平方向への浸透は小さいと考えられる。よって河 川のごく近傍にのみ高イオン濃度域が形成される。 その一方, Sand-Pocketの建設によって天井川化 が進行した Pasig-Potrero 川流域の三角州周辺で は, 河床面が堤内地より高いため, 河川水が周辺 地域へ浸透しやすい環境が存在する。 


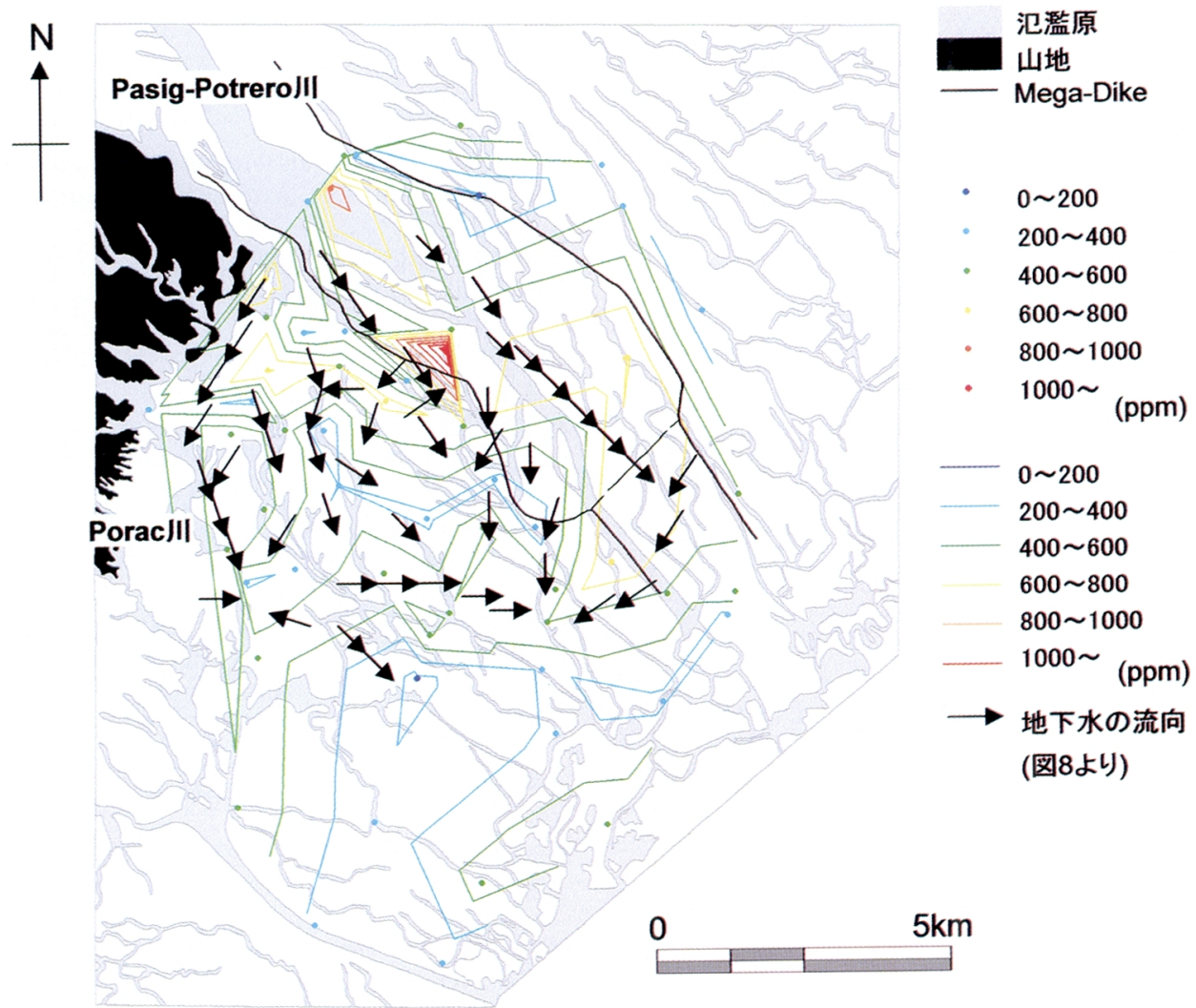

四 $16 \mathrm{SO}_{4}{ }^{2-}$ イオンの分布と地下水の流向 (2002 年06 月).

Fig. 16 Relationship between Regional distribution of $\mathrm{SO}_{4}{ }^{2-}$ ion and underground water flow (Jun 2002).

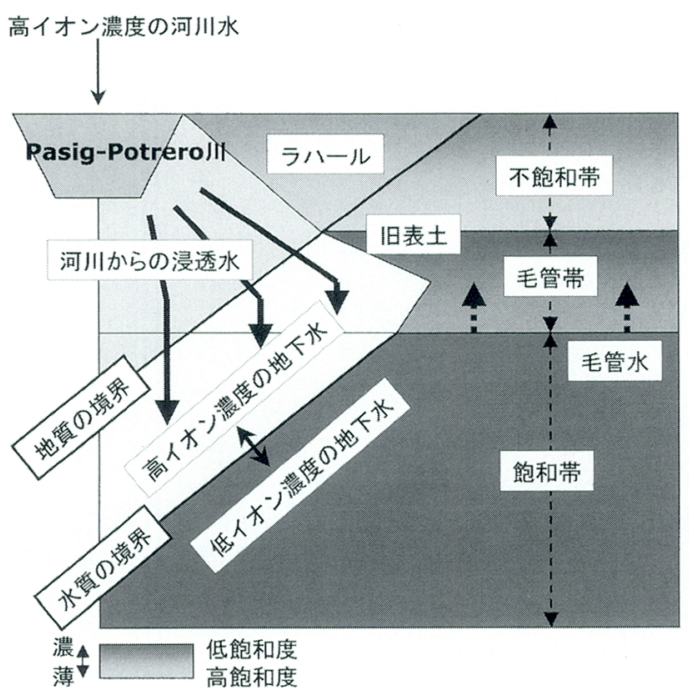

図 17 水質の形成過程モデル.

Fig. 17 Model of water quality.
また, 雨季末期から乾季にかけての $\mathrm{SO}_{4}{ }^{2-}$ 高濃度 域が縮小する要因として，Pasig-Potrero川中・ 下流域に扮ける河川水がその要因として考えられ る。すなわち Pasig-Potrero 川は乾季においては 中・下流域で定常的な河川水を欠くため, 河川水 の地下水に対する浸透が減少し，高濃度域が縮小 するものと考元られる。一方雨季においては，降 雨によって河川水のイオン濃度は低下するものの, イオン供給の総量は増加するため, 高濃度域が増 大するものと考えられる。

\section{VI. 結 論}

本研究により Pasig-Potrero 川流域に掞いては, 地形が地下水流動に強い影響を与えることが明ら かとなった。特にSand-Pocketの周辺においては, 
河川の天井化の影響が大きい。

また, $\mathrm{SO}_{4}{ }^{2-}$ 濃度の地域分布は, 地下水流向と,

Pasig-Potrero 川の河川水の有無に影響を受ける

ことが示唆された。

これらの結果から, Pasig-Potrero 川を中心と する地下水質の形成過程モデルが推察された。

冒頭で述べたように，本地域においては地下水 が重要な水資源となっているが, 地下水の量・質 は利用上大きな問題となる。特に飲料水・農業に 影響を与える, 高濃度の $\mathrm{SO}_{4}{ }^{2-}$ が検出されたPasigPotreroka 川周辺では，地下水の量・質・用途な どを総合的に評価して，土地利用を決定する必要 があるものと考える。

\section{謝 辞}

本研究の一部は笹川科学研究助成の支援を受けて行つ た。ここに謝意を表する。

\section{文献}

Alicante, M.M., Rosell, D.Z., Marfori, R.T. and Hernandez, S. (1940): Soil Survey of Tarlac Province Philippines. Ministry of Agriculture, 2038.

Gosselin, D.C., Harvey, F.E. and Frost, C.D. (2001): Geochemical evolution of ground water in the Great plains (Dakota) aquifer of Nebraska: Implication for the management of a regional aquifer system. Ground Water, 39, 98-108.

Department of Public Works and Highways, Philippines (1998): Final Report for Pinatubo Hazard Urgent Mitigation Project Part III Monitoring and Planning on Lahar/mudflow Control Works in Pasig-Potrero River Basin.

Hendry, M.J. and Schwartz, F.W. (1990): The chemical evolution of ground water in the Milk river aquifer. Canada. Ground Water, 28, 253-261.

平出重信・ホセ＝ロンダル (2002): 噴火後の水の変化 と人々の生活. 吉田正夫編：自然力を知る. 古今書院, 101-108.

平出重信・鈴木浩一・渡邊眞紀子・森島 済・ Collado, M.B. - Rondal, J.D. ·澄川慎一朗 - 吉田正夫 · 大倉利 明 (2001): フィリピンピナツボ火山ラハール災害地 域に㧈ける地下水探査に関する基礎的研究。応用地質, 42, 274-285.

平出重信 · Collado, M.B. - Rondal, J.D. 鈴木浩一・森 島 済・渡邊眞紀子・衣笠善博 $(2002)$ : フイリピン Pasig-Potrero 川流域に扔ける地下水探査への電気探 查法垂直探查の適用性評価. 応用地質, 43, 239-243. 広瀬典昭・井上公夫 (1999): ピナツボ火山噴火後の地 形変化と土砂災害. 地形, 20, 431-438.
今井弘樹 (1992): ピナトゥボ火山爆発と泥流発生経過 その 1. ピナトゥボ火山の爆発。ペドロジスト, $\mathbf{3 6}$, 31-39.

Imai, H., Villajuan, E.C. and Grifal, R.B. (1993): Evaluation of extraction methods of sulfate in Mt. Pinatubo volcanic ashes. Soil Plant Nutr., 39, 357-360.

伊藤豊彰・山田大吾（1996）：ピナツボラハール由来土 䁃に扔ける塩基の溶脱. 南條正巳 : フィリピン・ピナ ツボ火山ラハール災害地带の環境回復と農業生産力の 向上に関する研究. 平成 7 年度科学研究費補助金（国 際学術研究) 研究成果報告書.

河野伊一郎 (1989): 地下水工学. 鹿島出版会.

国際協力事業団・フイリピン共和国公共事業道路省 (1993): ピナツボ被災民生活用水供給計画基本設計 調查報告書. $3-1$ p.

小屋口剛博（1991）：ピナツボ火山の噴火. 1991年 6 月 15 日. 火山, 36, 447-451.

森 和紀・坂寺一洋・榧根 勇・佐倉保夫 - 新見 治 田中 正・中井信之· Adnyana, M. - Jambe, A.A.G. N.A. Pawitan, H. $\cdot$ Suprapta, D.N. · Winaya, P.D. (1990): 熱带火山地域バリの水循環特性. ハイドロ ロジー, 20, 45-52.

守屋以智雄 (1978): 空中写真による火山の地形判読. 火山, 23, 199-214.

榆井 久 (1993): 地下水污染の水質基準と法的規制. 水収支研究グループ編：地下水資源・環境論 その理論 と実践. 共立出版, 163-166.

Newhall, C.G., Daag, A.S., Delfin, F.G. Jr., Hoblitt, R.P., Mcgeehin, J., Pallister, J.S., Regalado, M.T.M., Rubin, M., Tubianosa, B.S., Tamayo, R.A. Jr., Umbal, J.V. (1995): Eruptive history of mount Pinatubo. Mud and Flow. Washington Press, 165195.

小椋健二 (1999): フィリピンの経済と水事情その 2. 地下水技術，41(10)，33-41.

小椋健二 (2000): フィリピンの地下水基準と飲料水に 関する国家规格について。地下水技術，42(6)，9-13. 小野寺真一 (1996): 熱带半乾燥地域に抢ける集中的な 地下水涵養機構. ハイドロロジー, 26, 87-98.

大矢雅彦 (1983): 地形分類の手法々展開. 古今書院.

斉藤享治 (1983): 合流扇状地と合成扇状地. 関東の四 紀, 10, 43-47.

斉藤享治 (1994): 扇状地の発達に関する熱帯湿潤地域 と温帯湿潤地域の比較研究. 文部省科学研費補助金研 究成果報告書.

斎藤享治 (1995): 日本・台湾・フィリピンの現成扇状 地の分布と気温・降水量. 埼玉大学紀要教育学部 (人 文・社会科学)，44(2)，1-10.

嶋田 純 (1998):「地下水涵養と流出」I. 扇状地にお ける地下水涵養と流出. 日本水文科学会誌, $28,61-$ 67.

鈴木隆介（1997）：建設技術者のための地形図読図入門1. 読図の基礎. 古今書院.

Teodomero, M.Y., Isidoro, M.J. and Juanito, P.D. (1956): Soil Survey of Pampanga Province Philippines. Ministry of Agriculture, 39-41. 
过 藤吾 (1986): 火山灰土壌草地の硫黄供給能に関す る研究 VII. 草地試験法, 37, 50-57.

牛島恵輔・水永秀樹・加藤昭彦 (1987)：パソコンによ る電気探査デー夕の解析. 物理探査, 40, 423-435.

渡邊且紀子 (2002): 火山泥流災害地域の機能回復. 吉 田正夫編：自然力を知る. 古今書院，109-121.

Wolfe, J.A. and Self, S. (1993): Subduction arc volcanisum and hydrothermal mineralization:
Manila trench sector, Philippines. Phil. J. Volcanol., 1, 11-40.

山本荘毅 (1983): 地下水調查法. 古今書院.

吉田正夫 ·太田寛行 (2002): 火山からあふれ出た硫黄 化合物と硫黄をめぐる微生物. 吉田正夫編 : 自然力を 知る. 古今書院, 75-91.

(2003 年 2 月 24 日受付, 2004 年 4 月 19 日受理) 